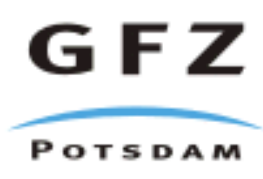

Originally published as:

Crewell, S., Mech, M., Reinhardt, T., Selbach, C., Betz, H. D., Brocard, E., Dick, G., O'Connor, E., Fischer, J., Hanisch, T., Hauf, T., Hünerbein, A., Delobbe, L., Mathes, A., Peters, G., Wernli, H., Wiegner, M., Wulfmeyer, V. (2008): The general observation period 2007 within the priority program on quantitative precipitation forecasting: Concept and first results. - Meteorologische Zeitschrift, 17, 6, 849-866

DOI: $10.1127 / 0941-2948 / 2008 / 0336$ 


\title{
The general observation period 2007 within the priority program on quantitative precipitation forecasting: Concept and first results
}

\author{
Susanne Crewell ${ }^{1 *}$, Mario MeCh $^{1}$, Thorsten Reinhardt ${ }^{1}$, Christoph Selbach $^{1}$, \\ HANS-DiETER BETZ ${ }^{2}$, EMANUEL BROCARD ${ }^{3}$, GALINA DICK ${ }^{4}$, EWAN O' CONNOR ${ }^{5}$, JÜRGEN \\ FisCHER $^{6}$, ThOMAS HANisCH ${ }^{7}$, ThOMAS HAUF ${ }^{8}$, ANJA HÜNERBEIN ${ }^{6}$, LAURENT DelOBbE ${ }^{9}$, \\ ARMin Mathes ${ }^{10}$, Gerhard Peters $^{11}$, Heini Wernli ${ }^{12}$, MatThias WiegneR ${ }^{2}$ and Volker \\ WULFMEYER ${ }^{13}$
}

${ }^{1}$ Institut für Geophysik und Meteorologie, Universität zu Köln, Germany

${ }^{2}$ Meteorologisches Institut, LMU München, Germany

${ }^{3}$ Institut für Angewandte Physik, Universität Bern, Switzerland

${ }^{4}$ Helmholtz-Centre Potsdam - German Research Centre for Geosciences (GFZ), Potsdam, Germany

${ }^{5}$ University of Reading, UK

${ }^{6}$ Institut für Meteorology, Freie Universität Berlin, Germany

${ }^{7}$ Deutscher Wetterdienst (DWD), Offenbach, Germany

${ }^{8}$ Institut für Meteorologie und Klimatologie, Universität Hannover, Germany

${ }^{9}$ Royal Meteorological Institute of Belgium, Brussels, Belgium

${ }^{10}$ Meteorologisches Institut, Universität Bonn, Germany

${ }^{11}$ Universität Hamburg, Germany

${ }^{12}$ Institut für Physik der Atmosphäre, Universität Mainz, Germany

${ }^{13}$ Institut für Physik und Meteorologie, Universität Hohenheim, Germany

(Manuscript received February 29, 2008; in revised form October 3, 2008; accepted October 3, 2008)

\begin{abstract}
In the year 2007 a General Observation Period (GOP) has been performed within the German Priority Program on Quantitative Precipitation Forecasting (PQP). By optimizing the use of existing instrumentation a large data set of in-situ and remote sensing instruments with special focus on water cycle variables was gathered over the full year cycle. The area of interest covered central Europe with increasing focus towards the Black Forest where the Convective and Orographically-induced Precipitation Study (COPS) took place from June to August 2007. Thus the GOP includes a variety of precipitation systems in order to relate the COPS results to a larger spatial scale. For a timely use of the data, forecasts of the numerical weather prediction models COSMO-EU and COSMO-DE of the German Meteorological Service were tailored to match the observations and perform model evaluation in a near real-time environment. The ultimate goal is to identify and distinguish between different kinds of model deficits and to improve process understanding.

Zusammenfassung

Im Jahr 2007 fand die sogenannte General Observation Period (GOP) als Teil des Schwerpunktprogramms "Quantitative Niederschlagsvorhersage" (PQP) statt. Durch die Optimierung existierender Beobachtungen konnte ein umfangreicher Datensatz von in-situ- und Fernerkundungsdaten mit Schwerpunkt auf Variablen des Wasserkreislaufes über ein volles Jahr gewonnen werden. Das GOP-Gebiet umfasste Zentraleuropa mit zunehmendem Fokus zum Schwarzwald, wo von Juni bis August 2007 das Feldexperiment COPS (Convective and Orographically-induced Precipitation Study) stattfand. Die GOP konnte dabei verschiedenste Arten von Niederschlagsereignissen beobachten und soll so COPS mit zeitlich und räumlich weiterreichenden Resultaten ergänzen. Um eine zeitnahe Nutzung der Daten zu ermöglichen, wurden die operationellen Vorhersagen der numerischen Wettervorhersagemodelle COSMO-EU und COSMO-DE des Deutschen Wetterdienstes so aufbereitet, dass eine Modellevaluierung nahezu in Echtzeit möglich wurde. Das Ziel dabei ist die Identifizierung und Unterscheidung verschiedener Modelldefizite zur Verbesserung des Prozessverständnisses.
\end{abstract}

\section{Introduction}

Precipitation forecasts are one of the most demanding applications in numerical weather prediction (NWP).

\footnotetext{
*Corresponding author: Susanne Crewell, Institut für Geophysik und Meteorologie, Universität zu Köln, Zülpicher Str. 49a, 50674 Köln, Germany, e-mail: crewell@meteo.uni-koeln.de
}

In contrast to other forecast variables, for quantitative precipitation forecasts no significant improvement could be achieved in the last decade (HENSE et al., 2006). A general problem found in many NWP models is the diurnal cycle of precipitation (see for example GUICHARD et al., 2004) with convective precipitation simulated a couple of hours too early. Many ad- 


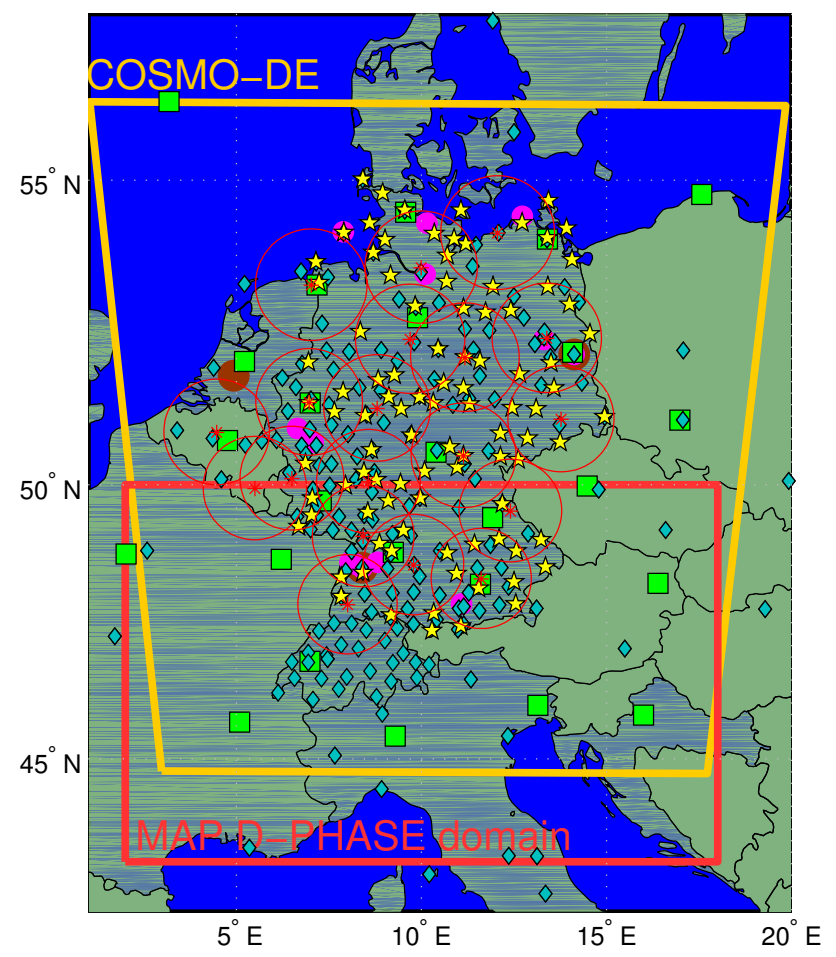

Figure 1: Map of GOP area indicating micro rain radar stations (pink circles), radio sounding stations (green squares), DWD ceilometer network (yellow), GPS network (blue diamonds) and $100 \mathrm{~km}$ radius (red circles) of Germany and Belgium weather radars (red stars). Furthermore, the domains of DWD's operational COSMODE model and the D-Phase models (see Section 4) are given.

ditional problems in precipitation forecast have been identified (e.g. too frequent forecasts of weak precipitation (EBERT et al., 2003), the windward/lee effect (WULFMEYER et al., 2008), high errors in extreme events, difficulties in distinguishing snow/rain, hail forecast) which are probably related to a number of different model weaknesses (errors in initial and boundary conditions, spin-up, interactions with the surface (soil moisture), cloud microphysics, convection parameterization, turbulence etc.). Many studies concerning model evaluation and improvement have been limited to specific regions (for example tropics (BECHTOLD et al., 2004)), specific precipitation types (for example winter storms in orographic terrain (STOELINGA et al., 2003)) or specific observation periods (for example GUICHARD et al., 2003). Precipitation forecasts are especially demanding because several non-linear processes connected to the generation of precipitation and their interactions need to be considered. This implies that not only precipitation but also many other parameters (water vapour, cloud and surface parameters, etc.) need to be observed. Because many of these parameters and especially precipitation have a large temporal and spatial variability the demands on the observing system are very high and are not fulfilled in operational model verification.
In order to tackle the above mentioned problems a priority program on "Quantitative precipitation forecast" has been initiated in Germany (HENSE et al., 2006). Within this program two observational approaches, the Convective and Orographically-induced Precipitation Study (COPS) experiment in the Black Forest during summer 2007 (WULFMEYER et al., 2008) and the General Observation Period (GOP, http://gop.meteo.unikoeln.de), were initiated to gather a solid observational basis to identify and improve NWP model deficits. Here we will describe the GOP effort aiming at the setup of a comprehensive reference data base of atmospheric and surface parameters suitable for extensive model evaluation and testing. In order to include different types of precipitation events, the GOP covers the full year of 2007 and the domain of Central Europe (Fig. 1).

Standard verification at weather services typically encompasses rain gauge networks, SYNOP stations and radiosonde ascents. As part of the GOP also the potential of new data sources for model evaluation shall be assessed. In this respect we focus on instrumentation (satellites, micro rain radar, ceilometer, GPS, groundbased supersites) that can provide long-term continuous observations allowing statistical robust model evaluation. In contrast, state-of-the-art instrumentation, for example 4D scanning remote sensing instruments, was operating during COPS intensive observation periods (IOPs) and will be used within COPS for process studies.

One of the problems in forecast evaluation and data assimilation lies in the (occasional) appearance of phase errors, when a forecasted weather system is displaced in time or space. This is especially true for convectivescale systems, where the errors are large due to the influence of subgrid-scale processes. Due to the stochastic nature of these effects it is crucial to produce longterm comprehensive data sets to identify systematic biases; some problems e.g. initial and boundary conditions might cancel out when longer time series are considered. Therefore quasi-realtime quality measures were calculated for the two operational short-range NWP models of the German Meteorological Service (DWD), namely COSMO-EU and COSMO-DE. The online visualization (http://gop.meteo.uni-koeln.de) helped to refine the automatic processing and allowed a timely use and wide distribution of the results.

This paper describes the different ingredients of the GOP, namely the different instrumental data sets (Section 2) and the corresponding model output (Section 3) which are both archived together at the World Data Center for Climate in Hamburg. In order to achieve timely results a near-real-time model evaluation has been implemented for a number of observations (Section 4). For the future the GOP data offer numerous opportunities for further model evaluation and case study selection. 


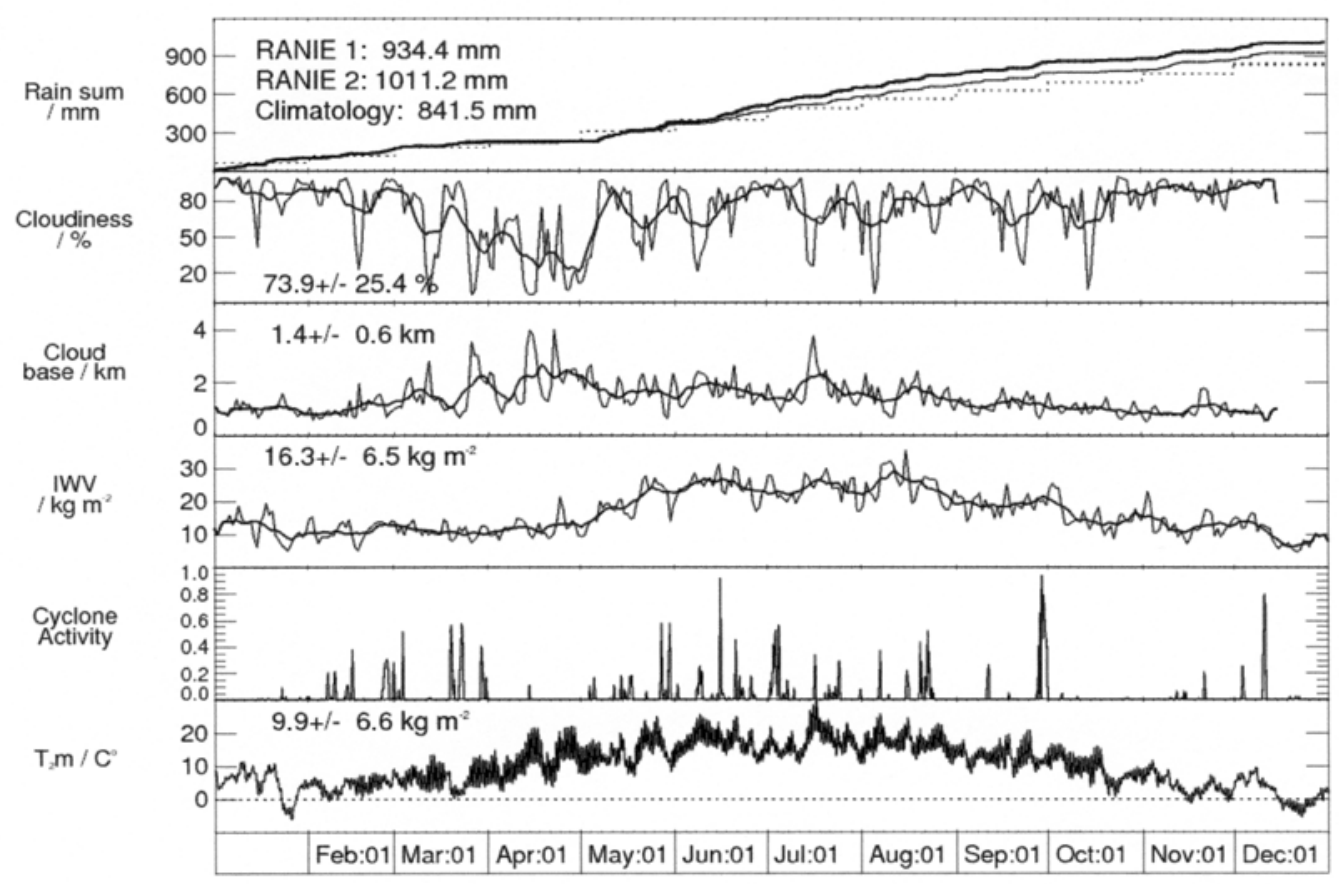

Figure 2: Overview of the GOP period 2007 in terms of daily accumulated surface precipitation averaged over whole Germany, daily mean cloud fraction and cloud base height from ceilometer network, integrated water vapour amount from GPS network, cyclone activity and and $2 \mathrm{~m}$ temperature (from top to bottom). The two latter parameters were derived from ECMWF analysis for a box $\left(5-15^{\circ} \mathrm{E} ; 47-55^{\circ} \mathrm{N}\right)$ with $6 \mathrm{~h}$ resolution. Cyclone activity is expressed through the fraction of area being under cyclone influence $(0-$ no cyclone; $1-$ cyclone). Due to the $6 \mathrm{~h}$ resolution the noisy structure in the lower most plot indicates a strong diurnal variation in $2 \mathrm{~m}$ temperature.

\section{GOP instrumentation}

The GOP observations have been grouped into eight categories starting with the key variable, precipitation at the ground, and extending to the detailed 3D structure of precipitation (weather radar) as well as information on microphysics (disdrometer). In addition to the precipitation-oriented observations other ground-based and space-borne observations connected to the development of precipitation were explored (GPS, lidars, lightning networks, diverse satellite instruments, meteorological observatories, etc.). In order to optimize the spatial coverage some existing instrumentation was redistributed. In particular the networks of GPS and micro rain radars were densified in the COPS region.

\subsection{Rain gauge observations}

Typically rain gauge observations at the ground serve as the basis for the verification of precipitation forecasts. Due to systematic and sampling errors, averaging over a longer period needs to be performed to better relate observation and model gridbox value. Consequently, precipitation fields derived from current gauge networks are commonly used for time integrations longer than an hour. Furthermore, the irregular distribution of rain gauges in space can cause biases towards regions that are better sampled. In order to enhance the network density, diverse operators of rain gauge networks normally not used for model evaluation were gathered, quality-controlled and combined to precipitation maps for various integration times at the University of Bonn (MATHES et al., 2008). These observations acquired by the Environmental Agencies, water authorities, and municipalities provide an independent data set of several hundred stations. A specific example for a municipal network is the dense (about 60), high-resolution (1 min) Berlin network. The GOP surface rain data set (Table 1) also includes the operational DWD products consisting of pure in-situ data, but also those blended with radar data. One example product is RANIE (REICH, personal communication, 2007) giving accumulated surface precipitation for $6 \mathrm{~h}$ periods on a $1 \times 1 \mathrm{~km}^{2}$ grid (Fig. 2). Two data sets, one from pure in-situ observations (RANIE1) and one composed of in-situ and radar information (RANIE2), are available. Unfortunately, the data from the approximately 3000 climate stations with one day resolution will only become available in their final form with about one year delay.

Total precipitation in 2007 has been slightly above the normal range with a dry April and a rather variable summer period (Fig. 2). Interestingly, the daily domainaverage derived from the two RANIE products is rather close within the first five months of the year. In sum- 
Table 1: Information on available GOP rain gauge data. The code name corresponds to the entry name in the CERA data base.

\begin{tabular}{|c|c|c|c|c|}
\hline & $\begin{array}{l}\text { Code in Cera } \\
\text { data base }\end{array}$ & $\begin{array}{c}\text { Number of } \\
\text { stations }\end{array}$ & $\begin{array}{c}\text { Time } \\
\text { resolution }\end{array}$ & $\begin{array}{l}\text { Availability with } \\
\text { 1-2 years delay }\end{array}$ \\
\hline $\begin{array}{l}\text { Berlin high density rain gauge } \\
\text { network }\end{array}$ & rai_berl & 60 & $5 \mathrm{~min}$ & Til June 2007 \\
\hline $\begin{array}{l}\text { German water authorities and } \\
\text { environmental agencies }\end{array}$ & rai_wafe & ca. 200 & $5 \mathrm{~min}$ & \\
\hline DWD online available gauges & rai_dwdl & $\begin{array}{l}<700 \\
<60\end{array}$ & $\begin{array}{l}1 \mathrm{~h} \\
1 \mathrm{~min}\end{array}$ & Up to now \\
\hline DWD climate stations & rai_dwd2 & $<3900$ & 1 day & \\
\hline DWD Ranie1 product - gauge only & rai_dwd3 & $\begin{array}{l}1 \times 1 \mathrm{~km} \\
\text { analysis }\end{array}$ & $6 \mathrm{~h}$ & Up to now \\
\hline $\begin{array}{l}\text { DWD Ranie } 2 \text { product - gauge plus } \\
\text { radar }\end{array}$ & rai_dwd4 & $\begin{array}{l}1 \times 1 \mathrm{~km} \\
\text { analysis }\end{array}$ & $6 \mathrm{~h}$ & Up to now \\
\hline $\begin{array}{l}\text { DWD Regnie product (first) gauge } \\
\text { analysis (all stations) }\end{array}$ & rai_dwd5 & $30^{\prime \prime} * 60^{\prime \prime}$ & 1 day & Up to now \\
\hline DWD Regnie product (final) & rai_dwd6 & $30 ", * 60 "$, & 1 day & \\
\hline
\end{tabular}
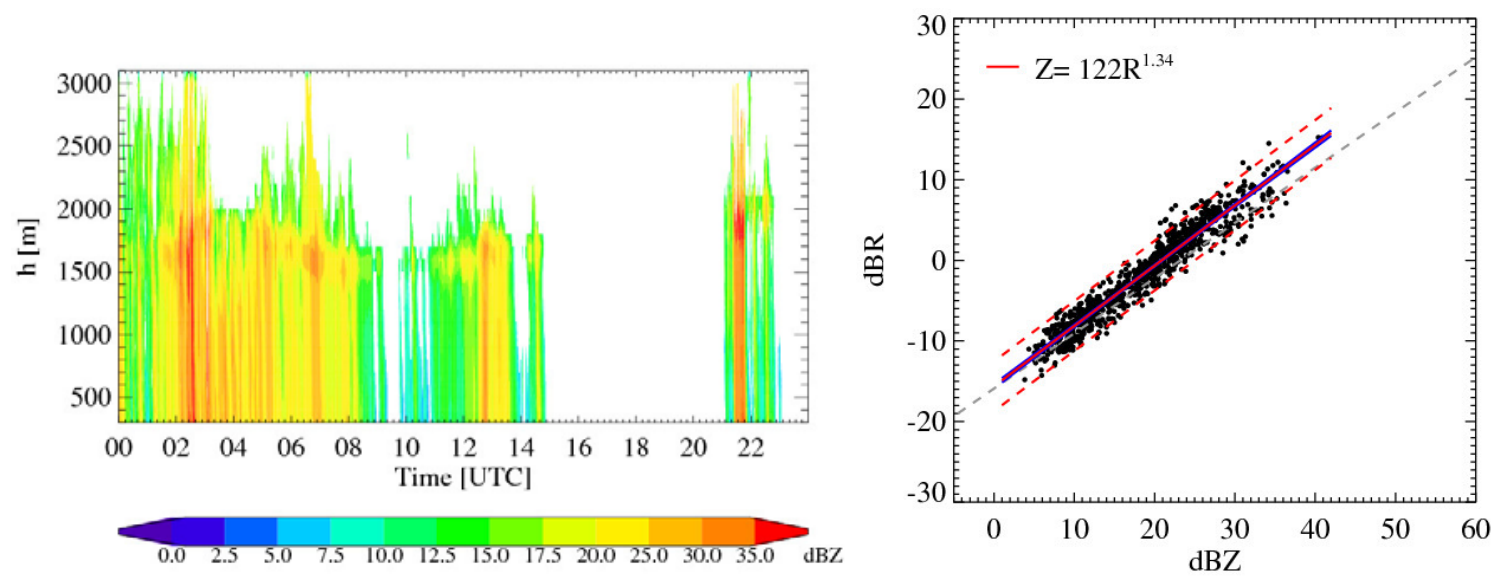

Figure 3: Time-height series of radar reflectivity (Z) on 1 June 2007 at the AMF Murg valley site (left) and the corresponding relation to rain rate $\mathrm{R}$ (right).

mer the radar product shows systematically higher values leading to $10 \%$ more precipitation over the year. The difference might be attributed to the fact that increased convective precipitation events in summer were missed by the sparse gauge network. However, a number of radar-related problems might also be the cause (see Section 2.2).

\subsection{Weather radar observations}

Weather radars provide information on the 3D distribution of hydrometeors with high temporal and spatial resolution. The German operational network (DEUTSCHER WETTERDIENST, 2008) encompasses several C-Band Doppler radars (Fig. 1) which perform volume scans roughly every $15 \mathrm{~min}$. A dedicated precipitation scan is performed every $5 \mathrm{~min}$ at the lowest elevation possible. Radar reflectivity as well as radial velocity are observed. The factors which limit rain rate accuracy can be divided into errors in the measurement of the radar reflectivity factor $\mathrm{Z}$, the conversion of $\mathrm{Z}$ into the rain rate $\mathrm{R}$, and the extrapolation from the measurement aloft to the precipitation at the ground. Radar calibration, attenuation, clutter, orographic shading, the assumption of Rayleigh scattering, and inhomogeneity within the radar volume contribute to the first class. The conversion from the radar reflectivity factor $\mathrm{Z}$ being the $6^{\text {th }}$ moment of the drop size distribution (DSD) to rain rate $\mathrm{R}$ is commonly done using the so-called Z-R relation, which strongly depends on variations in the DSD and therefore on the precipitation type and its temporal development. Extrapolation of the radar measurement at a certain height down to the surface leads to the largest problems (JORDAN et al., 2000) and causes differences of up to $50 \%$ in mean rain rates - even if averaged over $5 \times 5 \mathrm{~km}^{2}$. The problem is especially evident over mountainous regions where beam blocking makes such an extrapolation necessary. The above mentioned prob- 
lems add up to large uncertainties in the determination of the instantaneous precipitation intensity (between 30 and $100 \%$ ). Generally, the error increases with increasing distance to the radar (FABRY et al., 1992). Pragmatic approaches for improvement use adapted Z-R relations, e.g. DWD differentiates between winter and summertime precipitation, and/or local calibration using direct measurements at the surface (e.g., ROSENFELD et al., 1993; SOKOL, 2003).

For the GOP two calibrated radar products are available: DWD's RADOLAN product generates near realtime precipitation analyses from radar calibrated on-line by gauges. PAULAT et al. (2008) produce hourly precipitation maps from a combination of radar (composite of precipitation scans) and in-situ rain gauge data. Another alternative to better handle radar uncertainties is to simulate the radar observations from the model output by a so called radar simulator (HAASE and CREWELL, 2000; PFEIFER et al., submitted). International and national composite data by DWD and the Royal Meteorological Institute of Belgium (RMI) is available. Belgian radar data include observations from the Wideumont radar operated by RMI and from the Zaventem radar operated by Belgocontrol. For the German network a quality flag product developed by DWD (HELMERT et al., 2008) is available to prepare the radar data for assimilation via latent heat nudging. The product significantly reduces spurious precipitation signals caused by problems close to the radar locations (so-called German Pancakes), spokes due to beam blockage or external transmitters, and remnants of ground clutter, signals of ships, anomalous propagation or wind parks. The full 3-D radar reflectivities and radial velocities are available for six of DWD's 16 weather radars covering the COPS region from end of June onward. Further details about the available products are available via the web site http://gop.meteo.uni-koeln.de.

\subsection{Drop size distribution observations}

Micro rain radars (MRR) are a relatively new type of instrument which observes the vertically-resolved Doppler spectrum. By assuming a relationship between drop size and the vertical velocity the DSD can be derived. Further products include the vertical profiles of liquid water content (LWC), radar reflectivity factor $\mathrm{Z}$, mean vertical velocity of rain drops, and rain rate. A detailed error analysis has been performed by PETERS et al. (2005) on a theoretical basis and by comparison with surface disdrometer. It was found that the deviations of the MRR DSDs from the in-situ DSDs are in the same range as the mutual deviations of the in-situ DSDs. Recent longterm studies with MRRs in the Baltic Sea area have revealed significant height dependences of DSD parameters between surface and melting layer (PETERS et al., 2005), which are relevant for future physically based weather radar calibrations. In addition, systematic differences were found over land and sea (BUMKE et al., 2005).

In order to investigate precipitation microphysics a network of about 14 MRR-sites was implemented as part of the GOP (Fig. 1). Within the COPS area a transect of five sites was established in coordination with the polarimetric weather radar POLDIRAD which regularly performed elevation scans along that transect during COPS. Further locations included different geographic regions such as Helgoland in the North Sea, Berlin and Lindenberg in flat Eastern Germany as well as some sites in the low mountain ranges (Bonn). At eight stations additional surface disdrometers of different types (Joss-Waldvogel, Parsivel, optical disdrometers) were deployed. These instruments are based on different physical principles and methods for retrieving DSDs and can help to keep the major uncertainty of MRR-based DSDs under control, namely a potential bias due to vertical wind. The observations already show that the relation between the radar reflectivity and the rain rates show considerable variations even during the course of one precipitation event (Fig. 3).

\subsection{Lidar observations}

LIDAR instruments can provide measurements of a number of atmospheric parameters and have been strong involved in COPS. However, continuous observations which are the focus of the GOP are difficult to perform with state-of-the-art systems. Therefore the GOP includes 1) a cooperation with European Aerosol Research Lidar Network (EARLINET) and 2) the use of lidar ceilometers which are based on much simpler techniques compared to research lidars but operate continuously.

EARLINET provides range-resolved aerosol profiles on a regular basis, approximately three times a week. The data (from all EARLINET stations across Europe) will be available in a data base open to the COPS community. The data include the height of the planetary boundary layer, aerosol backscatter, and extinction coefficient profiles typically for one or two wavelengths $(355 \mathrm{~nm} / 532 \mathrm{~nm})$. Cloud boundaries are not evaluated routinely, but can be extracted from the data upon request. Quality control standards have been established as part of the EARLINET network (MATTHIAS et al., 2004) and are routinely used. German EARLINET stations include Hamburg, Leipzig, Maisach, München and Garmisch. The regular EARLINET schedule will allow to derive statistical properties of aerosol in coordination with cloud observations.

Measurements from lidar ceilometers at more than 100 stations within Germany are available through DWD (Fig. 1) with 10 min resolution providing cloud base height with an accuracy better than $30 \mathrm{~m}$ for up to three layers but not the full backscatter profile. Because these data are in principle available on real-time 
base their use in model evaluation explores a new path for standard verification. It should be noted that cloudiness derived from the observations (Fig. 2) might be biased towards lower values due to the altitude limitation (mostly $7 \mathrm{~km}$ ) which depends on the actual ceilometer type. In addition, ice clouds are often not detected because they show much weaker gradients in the observed backscatter profile. Therefore, ceilometers are best suited for low-level water clouds (VAN MEIJGAARD and CREWELL, 2005).

\subsection{GPS observations}

The Global Positioning System (GPS) can be utilized to estimate the water vapour distribution in the atmosphere. The microwave signals (1.2 and $1.5 \mathrm{GHz}, \mathrm{L}-\mathrm{Band})$ transmitted by the GPS satellites are delayed by the different atmospheric constituents. Therefore, the delays retrieved from the observations contain information on atmospheric properties, e. g., the water vapour content. The delays can be estimated using high precision GPS satellite orbits and receiver positions. Ionospheric effects on the signal propagation can be corrected in order to eliminate the contribution of the electric neutral atmosphere, which contains the water vapour information. This neutral atmosphere delay is dominated ( $\sim 90 \%)$ by the contribution induced by dry components, which show no permanent polarization (nitrogen, oxygen). This delay is also named as "hydrostatic" and can be described by empirical models, which estimate the vertical "dry" refractivity profile from the surface pressure. The remaining wet delay is induced by the interaction of the GPS signals with the permanent dipole moments of the water vapour molecules. The wet delay is taken as the difference between the observed total delay and the hydrostatic delay (DICK et al., 2001). From the various links to the GPS satellites an averaged zenith wet delay (ZWD) for the respective GPS ground station location can be derived, taking into account their different elevations.

The ZWD is closely related to the integrated water vapour (IWV) with $1 \mathrm{~kg} \mathrm{~m}^{-2}$ corresponding to approximately $6 \mathrm{~mm} \mathrm{ZWD}$. The accuracy of the derived IWV can be improved by estimating the effective atmospheric temperature, which can be approximated from the ground-level temperature. Several intercomparison studies (e. g. VAN BAELEN et al., 2005) demonstrated the potential to obtain the IWV over land with a good accuracy of $1-2 \mathrm{~kg} \mathrm{~m}^{-2}$. For the GOP, GFZ provided near-real time IVW data with a temporal resolution of 15 minutes and accuracy of 1-2 $\mathrm{mm}$ for a German GPS network consisting of approx. 200 stations during the GOP. Additional data from the Swiss Agnes GPS network are available. In order to achieve a better data coverage in the COPS region five extra stations were installed and operated for up to six months by GFZ. This will in conjunction with the precipitation and cloud information help to better analyse the water cycle in that area. During the COPS period slant total delays (STDs) were processed by the GFZ, which provide better information on the spatial distribution of the water vapour. The STD data have been validated to agree within $\sim 10 \mathrm{~mm}$ with independent observations (BENDER et al., 2008) and can be used to reconstruct the water vapour distribution either by assimilating them to NWP weather models or by tomographic techniques.

\subsection{Lightning networks}

The information on lightning and its distribution provides a valuable tool for nowcasting and short-term forecasts of convective precipitation and thunderstorms, since the electrical activity is closely related to cloud and storm parameters as well as characteristic storm phenomena (e.g. convective precipitation). Lightning networks are nowadays able to detect lightning with high temporal and spatial resolution. The two networks which contribute to the GOP are further able to distinguish between cloud-to-ground discharges (CG) and intra-cloud discharges (IC). LINET is a European lightning location network with presently 80 sensors; in a co-operation between University of Munich and DLR the network data is provided for the GOP campaign (www.pa.op.dlr.de/linet/index.html). LINET utilizes low frequencies $(5-200 \mathrm{kHz})$, whereby discrimination is performed with a time-of-arrival (TOA) 3Dtechnique. Due to optimised use of TOA the average locating accuracy is $\sim 200 \mathrm{~m}$ (BETZ et al., 2004). The second network is a SAFIR (Surveillance et Alerte Foudre par Interférometrie Radioélectrique) system of the University of Hannover in Northern Germany that consists of three stations in Ruthe, Senden and Brake with a sensor baseline of $170 \mathrm{~km}$. It detects leader steps by means of 2-dimensional direction finding in the VHF range (110-118 MHz), emitted by both IC and CG discharges; detection of CG-strokes and discrimination between IC and CG is performed with the help of an additional sensor that operates in the low-frequency regime (FINKE et al., accepted). An example for both networks is given in Fig. 4 for 22 June 2007 when more than 50000 lightnings occurred in the GOP area.

\subsection{Satellite observations}

Satellite observations have the advantage that large model areas can be covered and in case of geostationary satellites the high repetition times allow to study the temporal development of cloud systems. Therefore the Spinning Enhanced Visible and InfraRed Imager (SEVIRI) on Meteosat Second Generation (MSG) with its eleven spectral channels from 0.6 to $14 \mu \mathrm{m}$ plays a major role for the GOP. The calibrated satellite data were processed automatically to provide higher-order, level 2 products, such as water vapour and cloud top pressure at FU Berlin. The considered data products and 


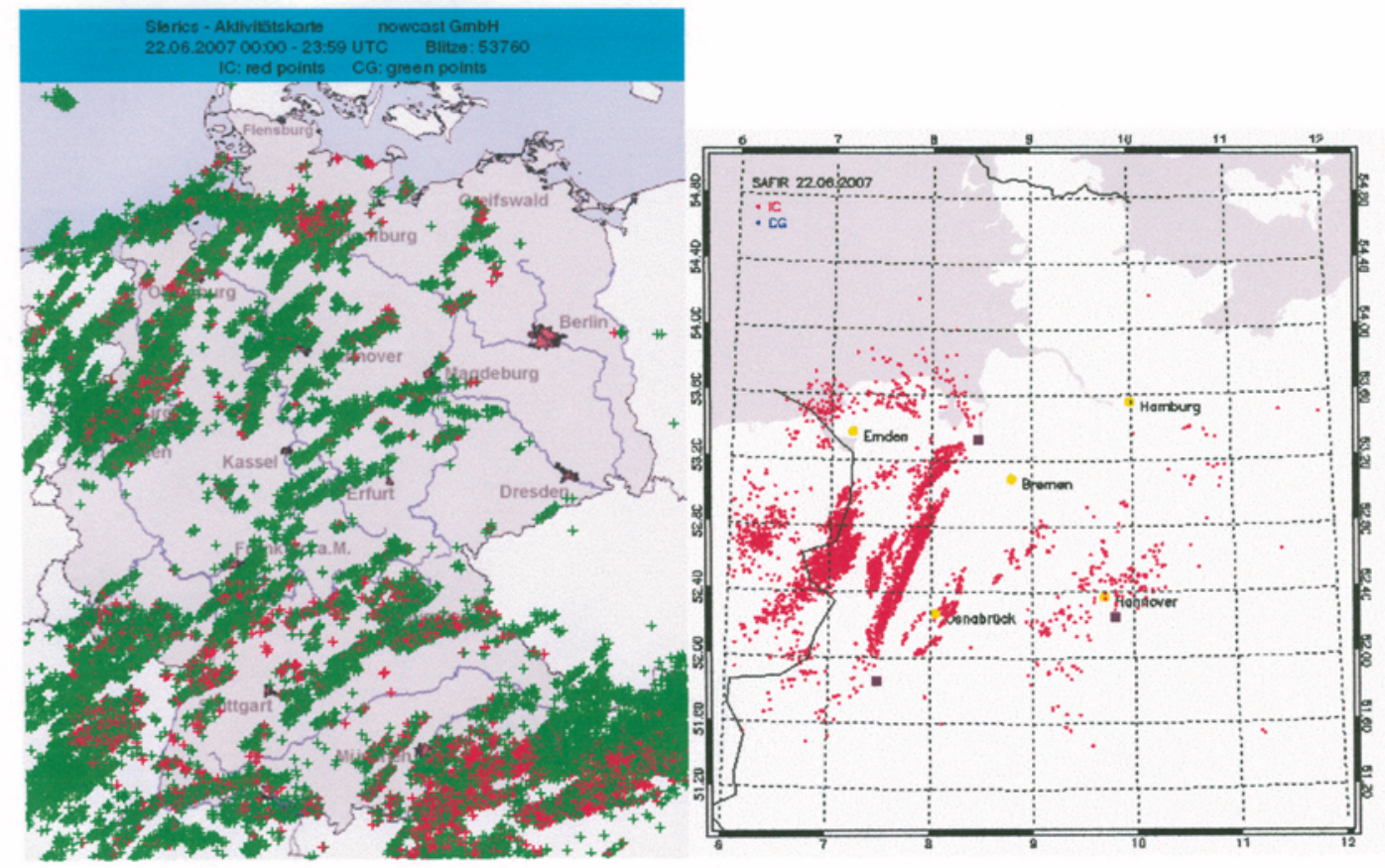

Figure 4: Examples for LINET (left) and the North German lightning network (right) for June 22, 2007.

Table 2: Overview on satellite sensors and the respective products for the GOP. Table A: Overview of satellite spatial resolution $\Delta \mathrm{x}$ and available products (TCI: near true color image, CM: cloud mask, BT: brightness temperature, IWV: integrated water vapor, CTP: cloud top pressure, $\tau$ : cloud optical thickness, $r_{\text {eff }}$ : effective radius of liquid water droplets, LWP: liquid water path, N: number concentration of cloud droplets, H: geometric cloud thickness, $\tau_{A}$ : aerosol optical thickness, A: Ångström coefficient). In addition a typical accuracy estimate $\sigma$ is given which might vary significantly with environmental conditions.

\begin{tabular}{|c|c|c|c|}
\hline Instrument & Technical & Products & Information \\
\hline $\begin{array}{l}\text { SEVIRI / } \\
\text { Meteosat-8 }\end{array}$ & $\begin{array}{l}\Delta \mathrm{x} \sim 5 \mathrm{~km} \text { over } \\
\text { Europe, } \Delta \mathrm{x} \sim 3 \mathrm{~km} \\
\text { nadir, whole disc } \\
\text { every } 15 \mathrm{~min} .\end{array}$ & $\begin{array}{l}\text { TCI, CM, clear } \\
\text { sky BT, IWV, } \\
\text { CTP }\end{array}$ & $\begin{array}{l}\text { BT accuracy } \sigma \sim 3.3 \mathrm{~K} \\
\text { IWV } \sigma \sim 0.7 \mathrm{~kg} \mathrm{~m}^{-2} \text { (day, clear } \\
\text { sky, land) } \\
\sigma \sim 52 / 121 \mathrm{hPa} \text { (high/low cl), }\end{array}$ \\
\hline $\begin{array}{l}\text { MODIS / } \\
\text { TERRA }\end{array}$ & $\begin{array}{l}\text { overpass Europe } \\
\sim 10: 30 \mathrm{am} \text {, resolution } \\
\text { at nadir } 0.3-1 \mathrm{~km}\end{array}$ & $\begin{array}{l}\text { TCI, CM, } \tau \text {, } \\
\text { LWP, reff, N, H, } 6 \\
\text { IWV, } \tau_{\mathrm{A}, \mathrm{A}}\end{array}$ & $\begin{array}{l}\text { microphysics for ocean and warm } \\
\text { boundary layer clouds } \\
\text { IWV clear sky land surfaces and } \\
\text { above clouds, } \sigma \sim 0.2 \mathrm{~kg} \mathrm{~m}^{-2} \\
\tau_{\mathrm{A}} \sigma \sim 0.05-0.3\end{array}$ \\
\hline $\begin{array}{l}\text { MODIS / } \\
\text { AQUA }\end{array}$ & $\begin{array}{l}\text { as MODIS/ TERRA } \\
\text { but overpass } \sim 1 \mathrm{pm}\end{array}$ & $\begin{array}{l}\text { Similar to } \\
\text { MODIS/TERRA }\end{array}$ & \\
\hline $\begin{array}{l}\text { MERIS / } \\
\text { Envisat }\end{array}$ & $\begin{array}{l}\text { overpass } \sim 10: 30 \\
\text { local, resolution at } \\
\text { nadir } 0.25-1 \mathrm{~km}\end{array}$ & $\begin{array}{l}\text { TCI, CM, } \tau \text {, } \\
\text { CTP, IWV }\end{array}$ & $\begin{array}{l}\text { CTP: } \sigma \sim 183 \mathrm{~m} \text { (single low-level) } \\
\text { clear sky, ocean, land and above } \\
\text { clouds }\end{array}$ \\
\hline AMSU / NOAA & $\begin{array}{l}\text { Overpasses } \\
\text { footprint }\end{array}$ & $\begin{array}{l}\text { TB at } 90,150, \\
183 \pm 1,3,7 \mathrm{GHz}\end{array}$ & $\begin{array}{l}\text { Window frequencies and } \\
\text { along water vapor line }\end{array}$ \\
\hline
\end{tabular}

their accuracy is given in Table 2. Within this near realtime processing also extraction of time series at 58 locations (see also Section 3) was implemented in order to monitor atmospheric products at meteorological stations within the COSMO-DE model domain, for example Cabauw and Lindenberg. Also the surrounding MSG pixels were archived in order to address spatial variabil- ity which is especially important in broken cloud situations. In addition to the production of time series, statistical information for selected regions like probability density functions of all thermal MSG brightness temperatures is stored to allow a routine evaluation of model forecasts. 


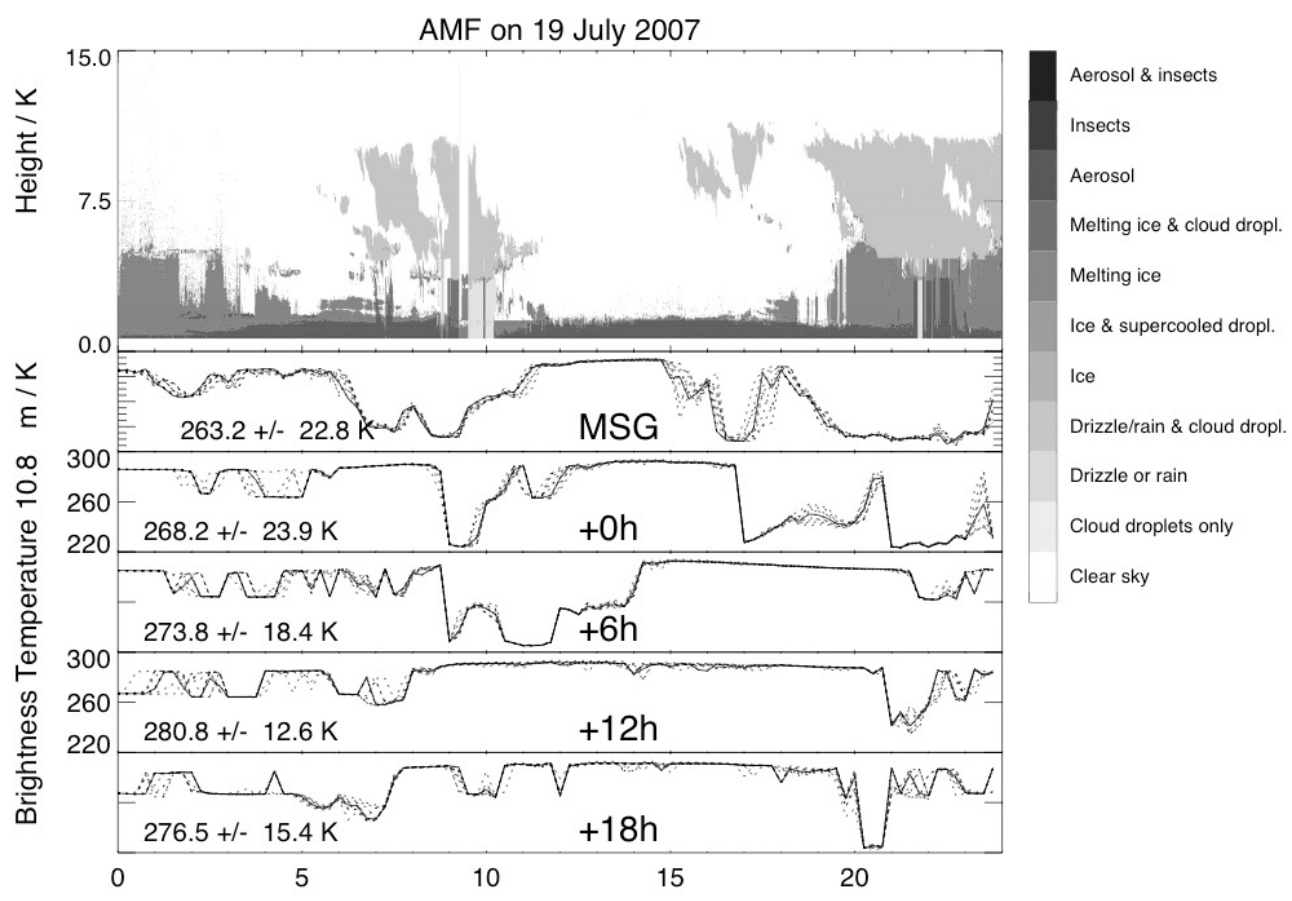

Figure 5: Vertical cloud classification derived from sensor synergy at the ARM site in the Murg valley on 19 July 2007 (top) together with corresponding brightness temperature at $10.8 \mu \mathrm{m}$ observed by MSG and simulated by the COSMO-DE model with different lead times. Here the annotation $+0 \mathrm{~h}$ corresponds to closest model forecast, e.g. since the COSMO model is started every 3 hours this means that at 00 , $03,06,09 \ldots$ UTC the analysis is shown while the value of $\mathrm{a}+1 \mathrm{~h}$ forecast is given $1,4,7,10 \ldots$ UTC. The mean value of $3 \times 3$ pixels grid / points (thick line) and individual data are shown for satellite / model.

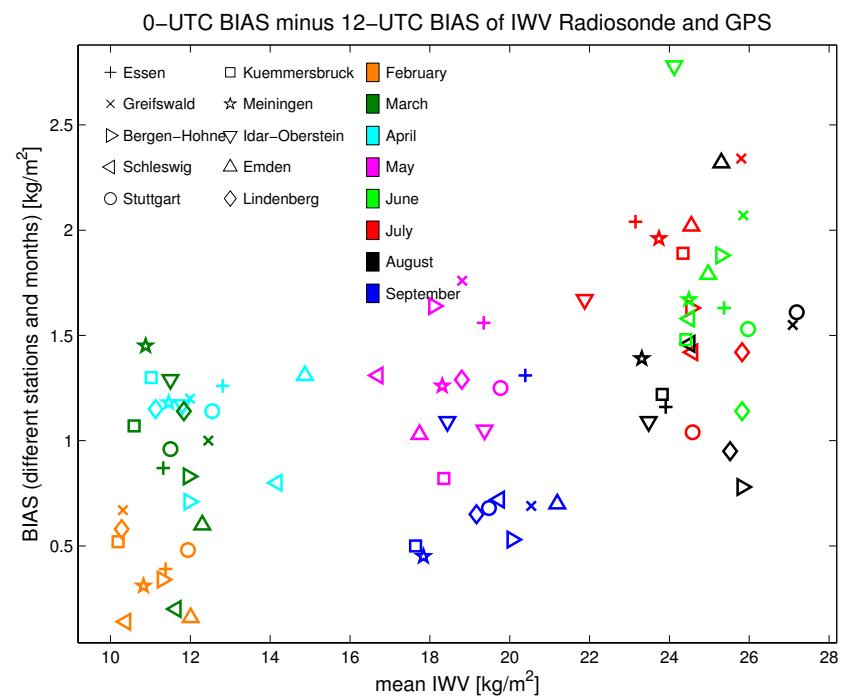

Figure 6: Mean difference between night-time and day-time IWV Bias (RS-GPS) for different radiosonde stations (symbol coded) and months (color coded).

The $10.8 \mu \mathrm{m}$ channel in the atmospheric window region is of particular interest as it shows a high contrast between clear sky with brightness temperatures (BT) close to the one of the surface and very low BT when the satellite observes cirrus clouds. The example in Fig. 5 il- lustrates that this channel serves as a good indicator for the quality of forecasted clouds. During the first 7 hours of 19 July 2007, varying brightness temperatures between 280 and $270 \mathrm{~K}$ corresponding to low level clouds are observed and predicted in a similar way. Two deep convective cloud systems produced precipitation on that day around 10 UTC and between 21-23 UTC. While the run closest to target time nicely captures the structures, the forecasts with different lead times do not reproduce the duration and strength of the system. Since this can also be caused by a spatial mismatch, the combined spatial-temporal development of cloud systems should be considered for example by tracking algorithms.

Also data from polar orbiting satellites are used. MODIS and MERIS provide high spatial resolution information on the cloud fields which is well suited to compare cloud patchiness in high resolution model forecasts (SCHRÖDER et al., 2006). Observations by the Advanced Microwave Sounding Unit (AMSU) onboard of the NOAA series are frequently used by weather services for temperature and moisture related assimilation. However, at the higher AMSU frequencies a high potential for hydrometeor retrievals exists (MECH et al., 2007). In particular they can reveal the cores of convective systems which are not detectable in the infrared since that signal mainly stems from the cloud top. 


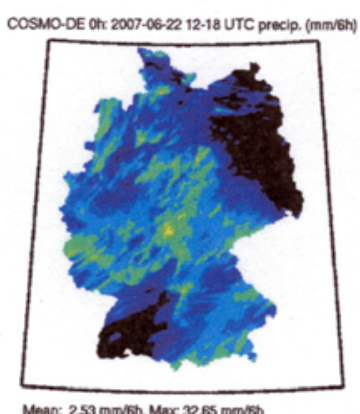

Mean: $253 \mathrm{~mm} / 6 \mathrm{~h}$, Max $32.65 \mathrm{~mm} / \mathrm{th}$

COSMO-DE -9tr 2007-06-22 12-18 UTC procip. (mm/Gh)

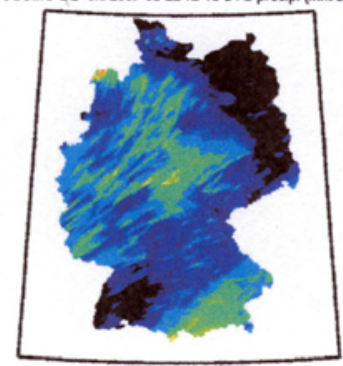

Mear: $273 \mathrm{~mm} / 6 \mathrm{bh}$, Max $43.74 \mathrm{~mm} / \mathrm{bh}$

COSMO-EU Oh 2007-06-22 12-18 UTC precip. (mmven)

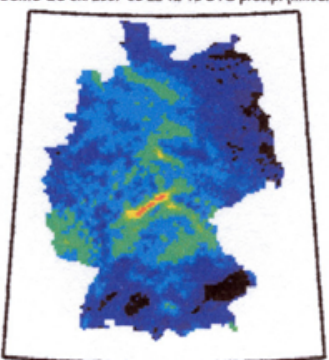

Mean: 2.71 mmveh, Maxc 34.88 mmveh

COSMOEU -9h 2007-06-22 12-18 UTC procip. (mmVEh)

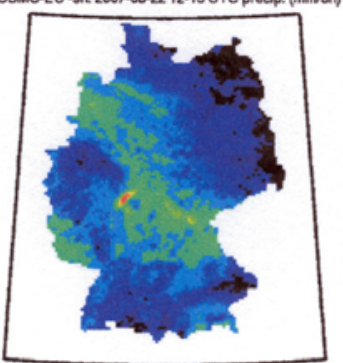

Mean: 273 mment Max 4332 mmvsh

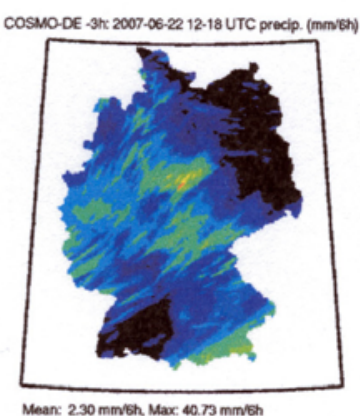

COSMO-DE -12h 2007-06-22 12-18 UTC precip, (mm/Gh)

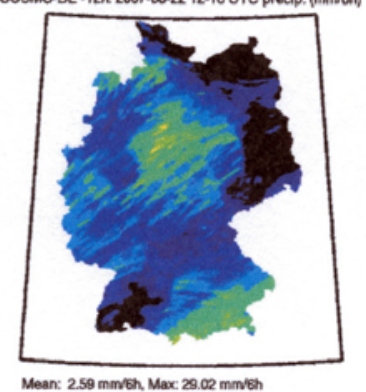

COSMO-EU-3r: 2007-06-22. 12-18 UTC procip. (mm/5h)

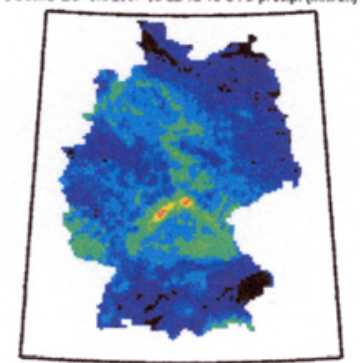

Mear: 2.49 mmsth, Maxc 33.67 mmsth

COSMO-EU - 12h 2007-06-22 12-18 UTC precip. (mm/Eh)

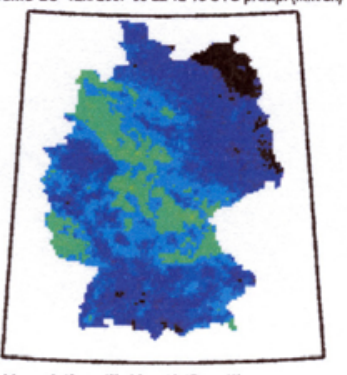

Mean: 248 mmet Max 18.15 mmeh

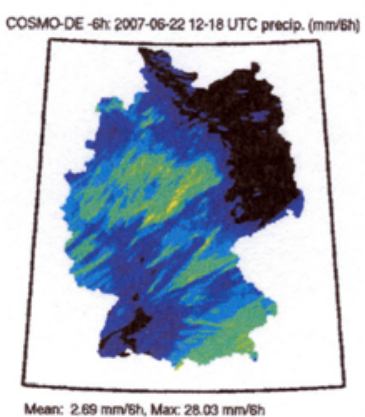

COSMO-OE -15h: 2007-06-22 12-18 UTC precip. (mImES)

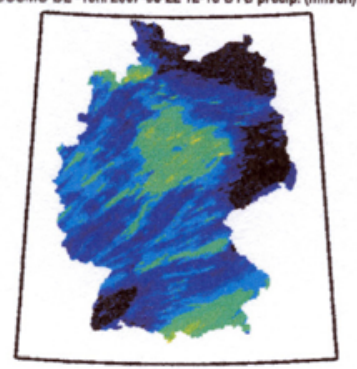

Mean: 272 mm/6h, Maxc $26.50 \mathrm{~mm} / \mathrm{bh}$

COSMOEU - -6r 2007-06-22 12-18 UTC precip. (mm/Eh)

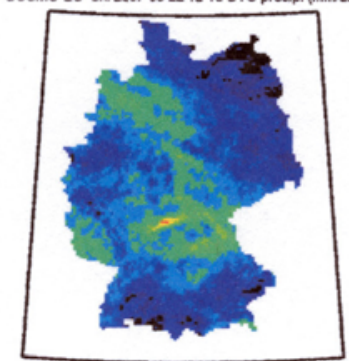

Mean: 294 mm/6h, Maxc 35.03 mm/Eh

COSMOEU -12h: 2007-06-22 12-18 UTC precip. (mm/Sh)

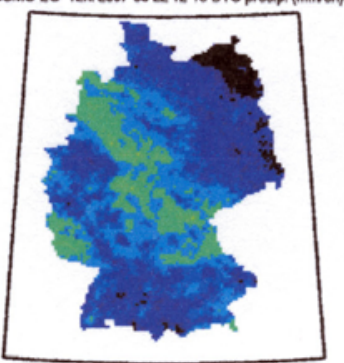

Mear: $248 \mathrm{~mm} / \mathrm{Eh}$ Max $18.15 \mathrm{~mm} / \mathrm{gh}$

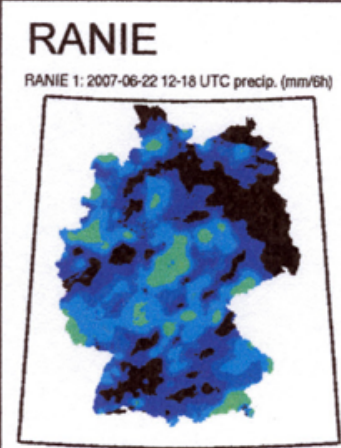

Mean: $1.70 \mathrm{~mm} / \mathrm{sh}$ Max. $15.70 \mathrm{~mm} / \mathrm{th}$

RANIE 2 2007-06-22 12-18 UTC precip. (mmm6h)

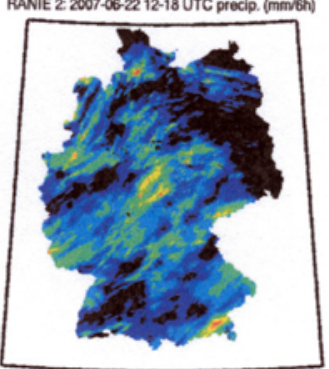

Mean: 298 mmVh Max 132.80 mmveh

Figure 7: Six-hourly accumulated precipitation for 12-18 UTC on 22 June 2007. Observed precipitation from interpolated gauges (RANIE1, top row, right) and blended gauge/radar product (RANIE2, second row, right), COSMO-DE (first and second row) and COSMO-EU (third and forth row) forecasts with lead times from $+15 \mathrm{~h}$ to $+0 \mathrm{~h}$. Lead time increasing from left to right and from top to bottom.

\subsection{Meteorological stations}

Detailed atmospheric observations are available at several sites operating a large number of complementary instruments. In addition to standard observations like radiosoundings, the GOP includes observations from several so-called supersites, e.g. the Atmospheric Radiation Measurements (ARM) program's Mobile facility
(AMF) stationed within the Black Forest from April to December 2007 and the Cloudnet sites Cabauw, Lindenberg and Chilbolton. The AMF is described in detail including the list of profiling and surface instruments (Table1 and 2) by MILLER and SLINGO (2007). The Cloudnet instrumentation and its use for model evaluation is detailed in ILLINGWORTH et al. (2007) and together with quicklooks at www.cloud-net.org/. At 

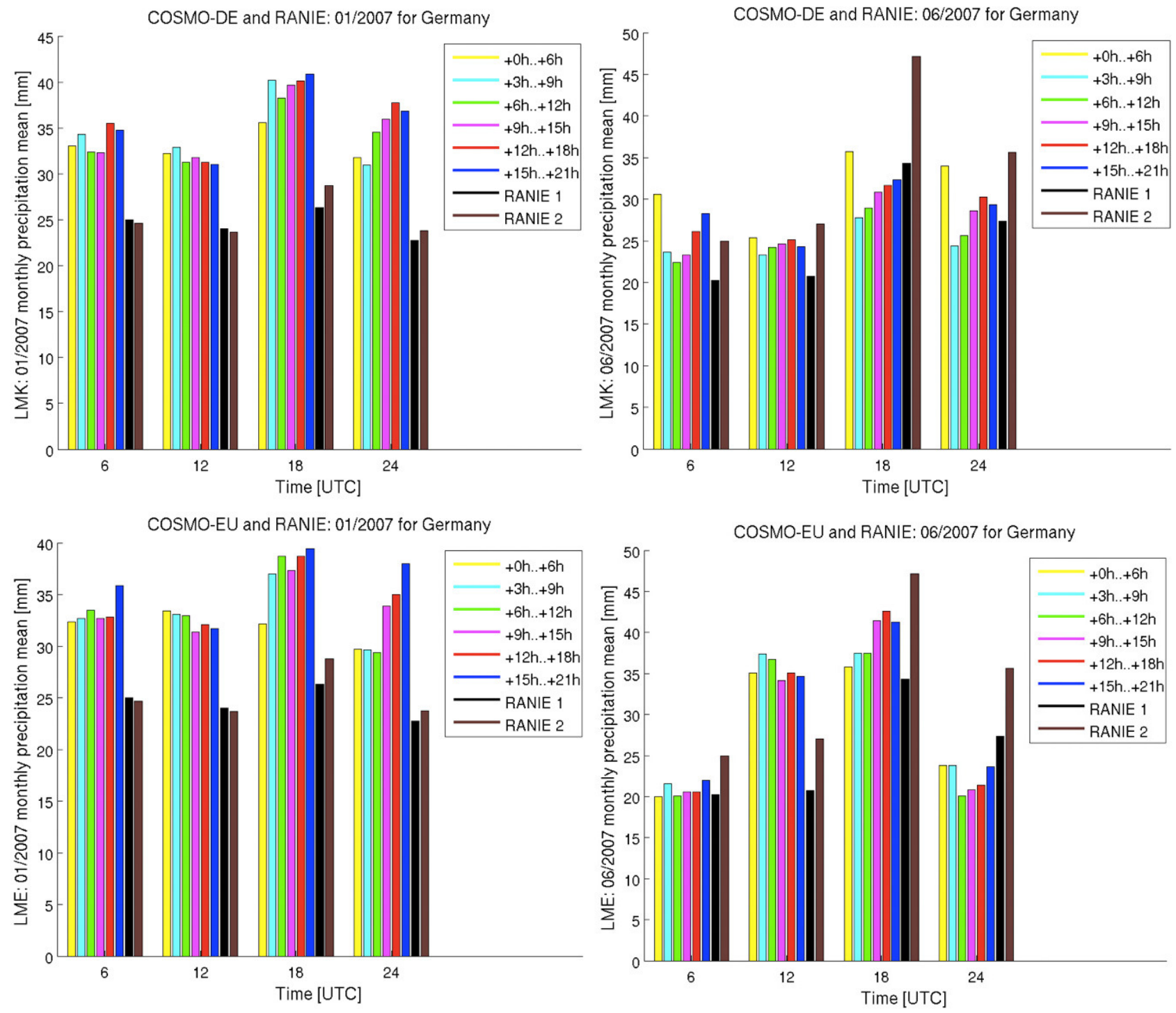

Figure 8: Diurnal cycle of monthly precipitation (mean over Germany) for COSMO-DE (top row) and COSMO-EU (bottom row) and the two RANIE products for January (left) and June (right). For each six-hour period the RANIE analyses and the forecasts with different lead times are indicated by different colours.

these stations their state-of-the-art instrumentation with strong complementary information provides a detailed picture of the atmospheric state. Here the combination of microwave radiometer, lidar, and cloud radar is especially powerful since microwave radiometers can provide information on the liquid water path, temperature and humidity profiles while cloud radar and lidar give highly resolved vertical profiles of radar reflectivity and backscatter, respectively. Depending on the instrument type further polarimetric and/or Doppler information is available. Because radar can penetrate most clouds and is sensitive to large particles together with the lidar which is more sensitive to smaller particles a detailed picture of the vertical hydrometeor structure (the so-called target classification, Fig. 5) can be derived. Based on such classification it is possible to use synergetic retrieval procedures (for example LÖHNERT et. al., in press) to derive profiles of liquid water content (LWC) and ice water content (IWC), e.g. the prognostic variables used by NWP models to represent clouds. Depending on the station many more observations, e.g. radiation, windprofiler etc, allow the characterization of the atmospheric state (in particular the boundary layer and clouds) with high detail. For these reasons such data have been extensively used for developing and testing model parameterizations, for example ZHANG et al. (2005) and WILLEN et al. (2005).

Further observatories of importance are the Swiss observational sites Zinndorf and Payerne, the Environmental station Schneefernerhaus and the Black Forest Observatories Hartheim and Tuttlingen which provide information from rather specific environments. Furthermore, university institutes often operate a rather complete set of instrumentation; as an example the available 
instruments at the Meteorological Institute Bonn consists of lidar ceilometer, microwave radiometer, infrared radiometer, micro rain radar, X-band radar, scintillometer, rain gauges, and a weather station.

\subsection{Consistency tests}

The specification of instrument uncertainties and individual characteristics is of uttermost importance for the quality of the GOP data base making quality control and cross checks mandatory. A well known problem has been the dry bias in RS-80 radiosondes (TURNER et al., 2003). Since nowadays most radiosondes launched are of the RS-92 type these were compared with IWV derived from GPS (see Section 2.5) for several stations with nearby GPS receivers at similar altitudes. It was found that - compared to GPS observations - 12-UTC IWV observations by radiosonde ascents were significantly dryer than those from 00-UTC ascents (Fig. 6). The bias between radiosonde and GPS IWV differs from station to station, but is for all stations greater at 12 UTC than at 00 UTC. A similar day-nighttime depending bias between GPS and RS measurements was already observed in earlier comparison studies (e.g., GENDT et al., 2004). The reason for this difference between 00 UTC and 12 UTC is probably a daytime dry bias of about $7 \%$ in radiosonde humidity measurements due to radiative effects (VÖMEL et al., 2007), whereas GPS IWV observations do not show such a dependency on the time of the day.

\section{Model output}

The GOP focuses on the performance of DWD's operational NWP applications of the COSMO model: COSMO-EU (formerly Lokal-Modell Europa, LME) and COSMO-DE (formerly Lokal-Modell Kürzestfrist, LMK). The COSMO model (formerly Lokal-Modell, STEPPELER et al., 2003) is a non-hydrostatic, fully compressible model in advection form. The model's prognostic variables are the 3 cartesian wind components $\mathrm{u}$, $\mathrm{v}, \mathrm{w}$, the deviations of pressure $\mathrm{p}^{\prime}$ and temperature T' from a hydrostatic base state and the mass fractions of moisture, cloud water, rain water, cloud ice, snow and (used in COSMO-DE only) graupel. The model physics include a level-2 turbulence parameterization, a delta2-stream radiation scheme, a multi-layer soil model, a grid-scale cloud and precipitation scheme, and a parameterization of moist convection (in COSMO-DE shallow convection only). The grid-scale microphysics parameterization is an extended Kessler-type single-moment scheme with mass fractions of cloud and precipitation condensate as prognostic variables. Detailed information on the COSMO model is given in the documentation by DOMS and SCHÄTTLER (2002) and DOMS et al. (2005). For data assimilation, the nudging method is applied (SCHRAFF and HeSs, 2003).
The current model chain at the DWD consists of the global hydrostatic model GME (40 vertical layers, mesh size $40 \mathrm{~km}$; MAJEWSKI et al., 2004; MAJEWSKI et al., 2002), therein nested the regional non-hydrostatic model COSMO-EU (40 vertical layers, mesh size $7 \mathrm{~km}$; SCHULZ and SCHÄTTLER, 2005), and therein nested the COSMO-DE. COSMO-DE (BALDAUF et al., 2006) is of particular interest due to its emphasis on the prediction of severe weather events related on the one hand to deep moist convection leading e.g. to super- and multicell thunderstorms or squall lines and on the other hand to interactions with fine scale topography. It covers Germany, Switzerland and Austria (therefore also the bigger part of the Alpine region, see Fig. 1), and smaller parts of their neighbouring countries with $421 \times 461 \times 50$ grid points and a horizontal grid spacing of $2.8 \mathrm{~km}$. A preoperational test phase for COSMO-DE started in August 2006, the operational usage started on 16 April 2007.

In the assimilation cycle of COSMO-DE highlyresolved rapidly-updated precipitation information from the German radar network is utilized applying the latent heat nudging (LHN; STEPHAN et al., 2008) approach (SCHRAFF et al., 2006). The COSMO model includes a forward radiative transfer model (Synthetic Satellite simulator, SynSat; KEIL et al., 2006) for the computation of synthetic radiances and brightness temperatures of eight MSG channels. These synthetic satellite data are computed and stored every hour in COSMO-EU and every $15 \mathrm{~min}$ in COSMO-DE. As a special feature, 21-h COSMO-DE forecasts are started every three hours from a continuous assimilation cycle. Therefore for each observation a lagged-forecast ensemble of up to eight different forecasts is available. This feature is well suited to investigate systematic model developments (see Section 4) and to explore how predictable certain situations are. In order to prepare a convenient model evaluation for all GOP data users, model output tailored to the observations is archived:

- Time series of the full model output are stored for 58 locations in total (http://gop.meteo.uni-koeln.de/gop/ doku.php?id=meteorological_stations) which correspond to major observational sites (radiosonde stations, COPS super sites, MRR locations, Cloudnet stations etc shown in Fig. 1). The representativity of the AMF-Murgtal, Payerne, Lindenberg and Cabauw sites is addressed by considering 3 by 3 gridpoints around the station. Many parameters of COSMODE output like the synthetic brightness temperatures, IWV, surface precipitation, and vertical wind are available at $15 \mathrm{~min}$ resolution.

- Time series information at the location of the instruments in GPS and ceilometer networks is extracted for the variables of interest in order to allow simple intercomparisons.

- Model fields for most interesting variables like precipitation rates, synthetic brightness temperatures are stored separately for an easy access. 

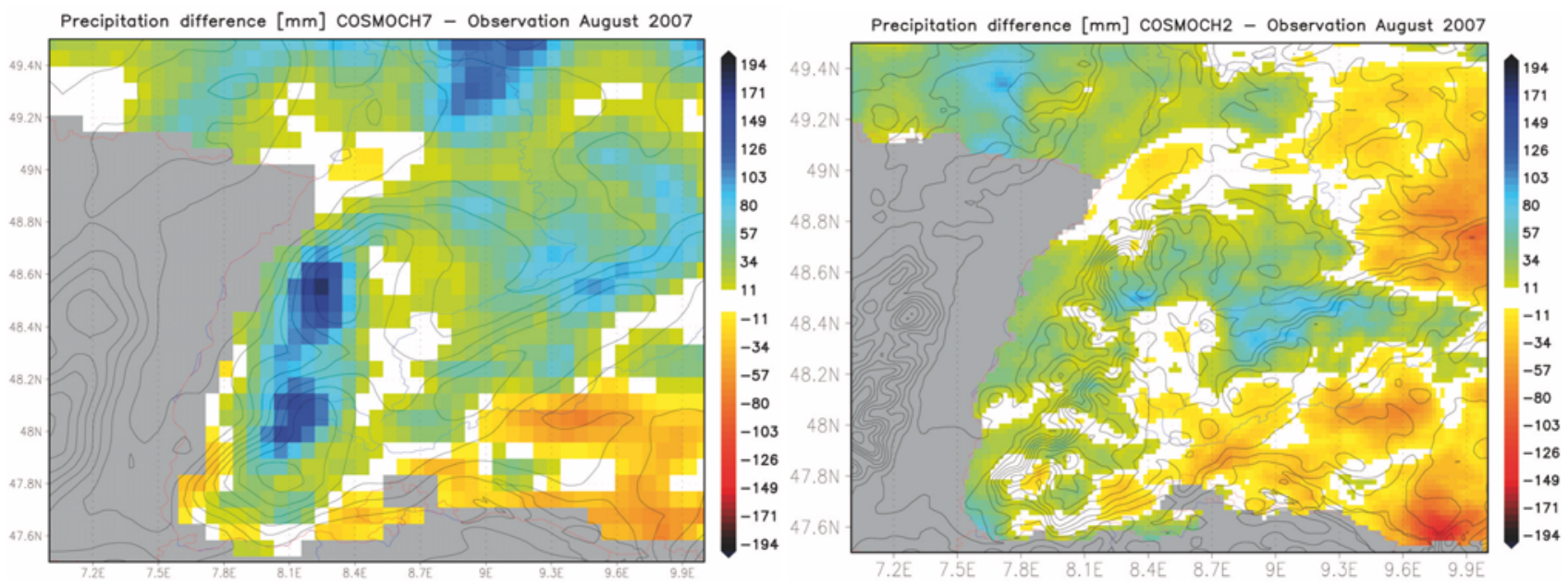

Figure 9: Difference in monthly precipitation for August 2007 between daily forecasts with the Swiss COSMO models with $7 \mathrm{~km}$ (left) and $2 \mathrm{~km}$ (right) resolution compared to rain gauge estimates for south-western Germany.

- Statistical information for different areas is archived in order to better identify certain locations or specific situations with especially good or bad model performance. In total 26 regions have been selected consisting of 13 catchment areas, seven geographic regions and six countries. Statistics include vertical and horizontal wind, cloud cover, precipitation, and integrated hydrometeor contents. This information will allow to perform conditional verification for various settings. For example situations with subsidence (vertical velocity) or those with unstable stratification can easily be extracted e.g. for weather-type dependent evaluation.

\section{Model evaluation}

The quality of model forecasted precipitation can be well illustrated by comparing it to analysed precipitation fields (Fig. 7). The difficulties in evaluating precipitation forecasts become immediately visible when two different observational products are used. For the case of widespread, convective precipitation (compare Fig. 4) the mean precipitation over Germany in a six hour period is $1.7 \mathrm{~mm}$ for a gauge interpolated product compared to $2.9 \mathrm{~mm}$ for the gauge/radar product with the model being in between with $2.53(2.71) \mathrm{mm}$ for COSMO-DE (-EU). One reason for the underestimation of the gauge product might be missing convective cells which pass between the gauges. However, also an overestimation might occur when radar observes graupel or hail which leads to high reflectivities that are wrongly converted to a high surface precipitation rate. Figure 7 also shows that COSMO-DE nicely reproduces the SW$\mathrm{NE}$ oriented tracks of convective cells also evident in the radar product while COSMO-EU is not able to simulate explicitly individual cells.

Though one can compare model forecasts and corresponding observations for single days at the GOP web site, systematic model behaviour is best investigated by looking at longer time averages. For example, a strong overestimation (20--30 \%) was found during winter in both models' precipitation forecasts (Fig. 8, left), which is not present in summer. In summer (June) COSMODE showed a better representation of the diurnal cycle of the precipitation than COSMO- EU, probably because of the explicit simulation of deep convection in COSMO-DE in contrast to parameterized deep convection in COSMO-EU (Fig. 8, right). In COSMO-DE forecasts in June it is also found that in the first forecast hours significantly more precipitation is simulated than later on which is probably caused by the utilization of the LHN method (Fig. 8, upper right). Figure 8 also reveals the difficulty in finding the correct value for precipitation; e.g. in June both observations differ significantly (see also Fig. 2) with the radar/gauge product being systematically higher. The reason for this might be that radar observations are affected by hail or graupel and subsequently are transformed via the standard Z-R relation to high surface rain rates. Therefore the final assessment of quantitative precipitation forecasts can only be performed when additional surface rain rate observations become available (see Section 2.1 and 2.2).

Within the scope of the coordination of D-PHASE, GOP, and COPS (WULFMEYER et al., 2008) a large set of state-of-the-art models (for example AROME, BOLAM, Meso-NH, MM5, and MOLOCH) could be evaluated. Particularly interesting was the question whether the new generation of convection permitting models is able to reduce systematic errors in complex terrain such as the windward/lee effect. Indeed, first results of the DPHASE project demonstrate that the windward/lee effect is substantially reduced. This is illustrated in Fig. 9 for the Swiss version of the COSMO model, which shows the difference between model forecasted and observed precipitation in the COPS domain for August if a model with convection parameterization (COSMO- 
January, 12007 to December, 31 2007, diurnal cycle, different model runs (COSMO DE minus obs) BIAS
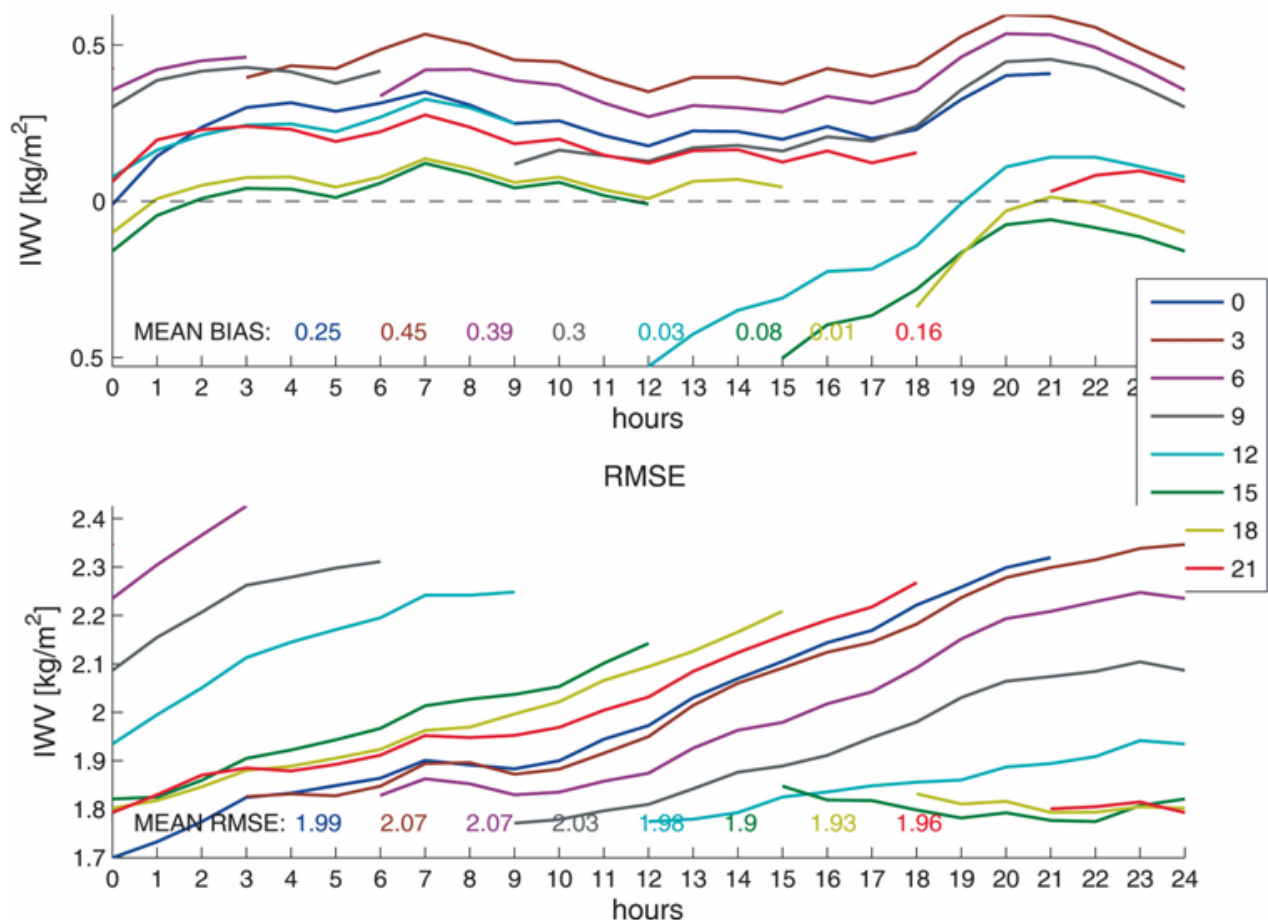

Figure 10: Diurnal cycle of Bias and RMSE for IWV (COSMO-DE minus GPS observation) for the full year 2007. The colours indicate the model runs started at different times of the day $(00,03, \ldots 21 \mathrm{UTC})$.

0 UTC "specific humidity" soundings: 411

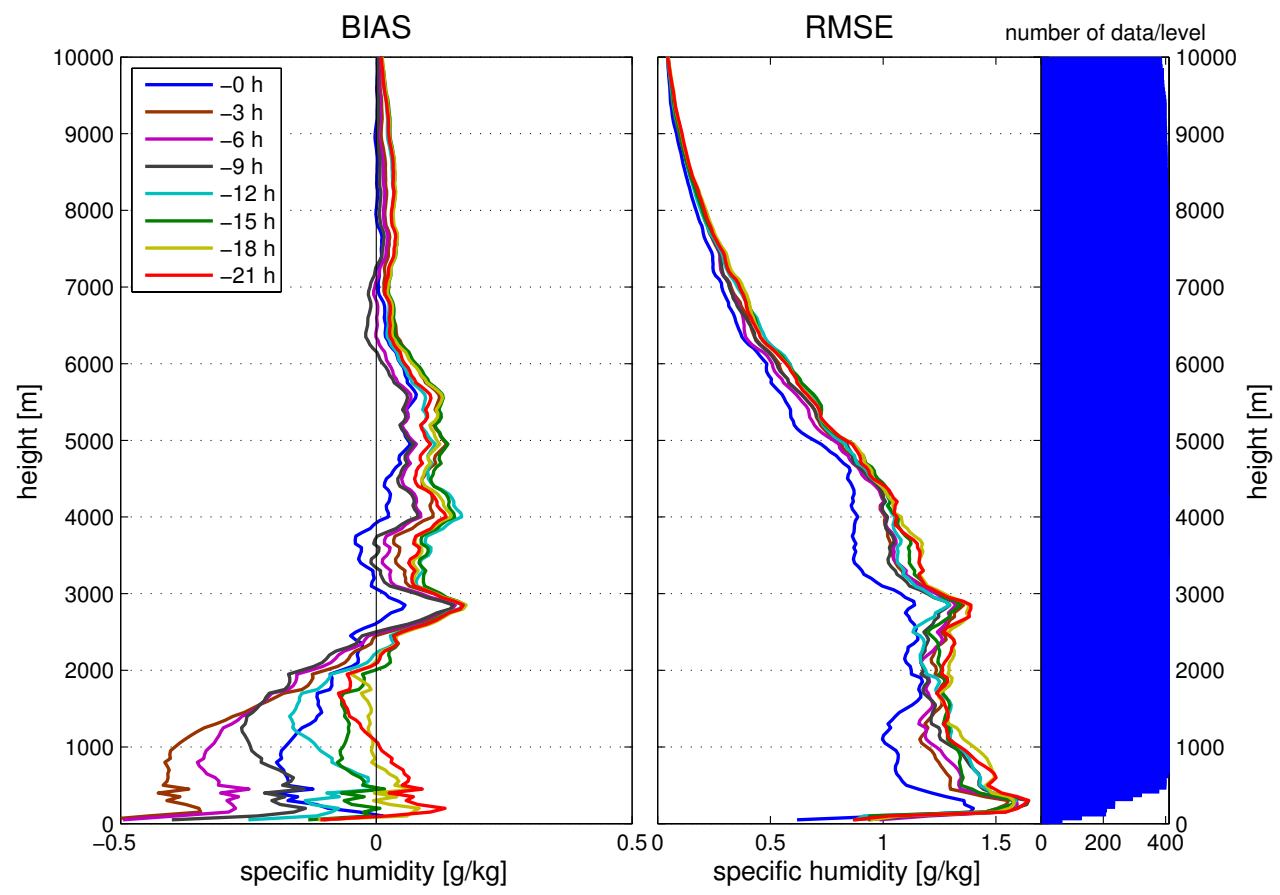

Figure 11: Bias (model-obs) and root mean square error in specific humidity at 00 UTC for all radiosonde stations passing a quality check within the COSMO-DE domain for July 2007. Different colours indicate different forecast lead times from the one started at 00 UTC (blue) to the $21 \mathrm{~h}$ forecast started at 3 UTC on the previous day (red). 
July 2007, (all stations) (COSMO-DE-runs minus obs)

BIAS (cloud base)

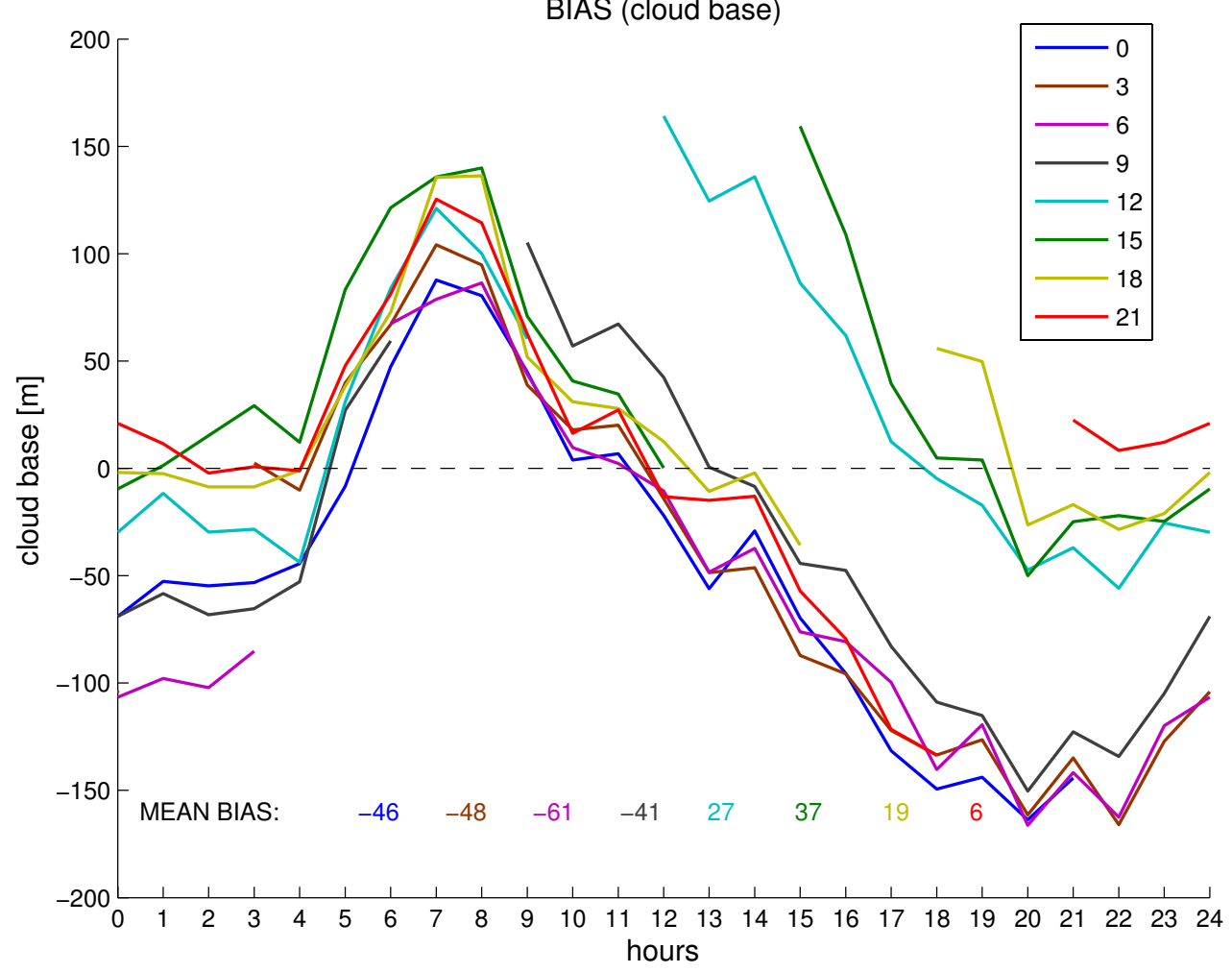

Figure 12: Diurnal bias of COSMO-DE cloud base vs. ceilometer cloud base (only data where a cloud below $3000 \mathrm{~m}$ was detected by the ceilometer and simulated by the model) for July 2007.

$2 \mathrm{CH}$ ) and another one without parameterization of deep convection $(\mathrm{COSMO}-7 \mathrm{CH})$ is studied. Similar reduction of models errors are found in nearly all convection permitting models, which have been investigated in the COPS domain within D-PHASE. Obviously, the convection parameterization used in the COSMO-7CH model, the revised Tiedtke scheme (TIEDTKE, 1989), triggers convection too often at the windward side of low mountains, whereas observations reveal that convection is triggered typically on the mountain ridges. Previously, corresponding systematic forecast errors caused strong limitations for the use of atmospheric models for flash flood forecasting. The new generation of convection permitting models seems to have a large potential for improving flash flood forecasting in complex terrain.

The comparisons above have shown some of the inherent difficulties of precipitation forecasts. In order to investigate if these might be related to other systematic model deficits we start with the water vapour as the basic variable in the hydrological cycle. The GPS network observations offer vertically integrated water vapour observations at high temporal resolution $(15 \mathrm{~min})$. For a statisticaly robust comparison we investigate the diurnal cycle of bias (COSMO-DE vs GPS observation) and root mean square error (RMSE) for IWV over the full year 2007 (Fig. 10). The striking point is that the IWV bias mainly depends on the start time of the model run.
The model runs started at 12,15 and 18 UTC (and, to some extent, at 21 UTC) are significantly drier than the model runs started at 00, 03, 06 and 09 UTC. We suppose that the reason for this behaviour is that in the first group of model runs the water vapour information from 12 UTC radiosonde ascents enters while in the second group of model runs the water vapour information from 00 UTC ascents is used in the initialitzation. In contrast to 00 UTC soundings, 12 UTC soundings have a dry bias due to radiative effects (see Section 2.9). A similar difference has already been identified by GUEROVA et al. (2003) using a previous version of the COSMO model for Switzerland. It is also interesting to note that the dry, e.g. 12, 15 and 18 UTC, runs only show the negative bias during the first approximately six hours of the forecast indicating that the model gains moisture with time either from the surface or through advection.

Since GPS only provides the total column values it is not clear at which altitudes the differences between observations and model occur. High-resolution vertical profiling at certain sites is performed by radiosondes (see Fig. 2) at synoptic times with highest repetition times of six hours at a few sites. Quicklooks for each ascent vs model forecasts as well as long-term statistical comparisons are available on http://gop.meteo.unikoeln.de/gop/doku.php?id=data_quicklooks. Temperature profiles are predicted rather well with a typical RMSE 

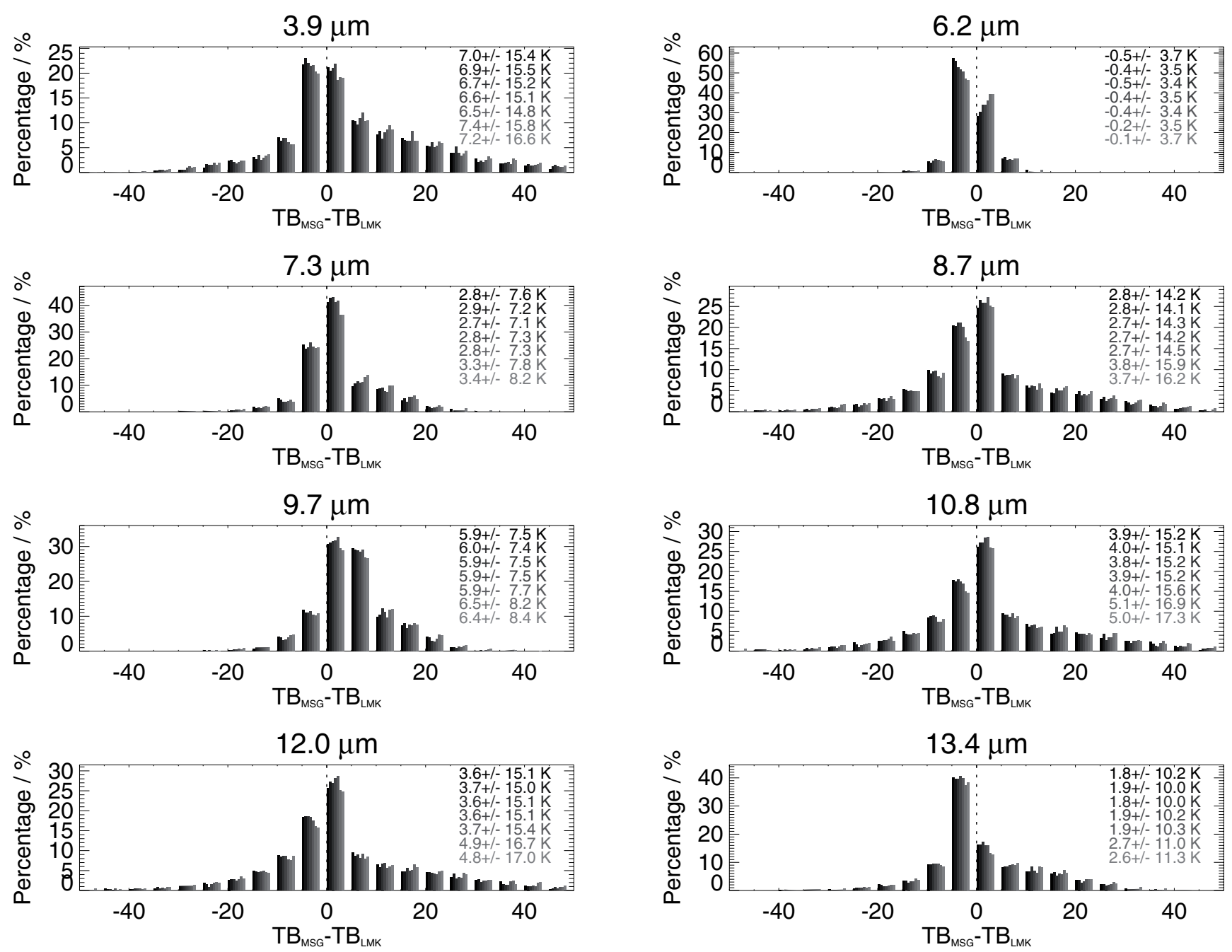

Figure 13: Probability distribution of difference between observed and simulated brightness temperatures for six different wavelengths for the July 2007 over the AMF site. The different grey scales indicate the lead time of black being the closest and light grey the longest model run.

of 1 to $1.5 \mathrm{~K}$ which only slightly increases with time (not shown). In addition, systematic differences in the boundary layer exist at some stations. The comparison of the vertical water vapour profile of radiosonde observations vs COSMO-DE forecasts for July 2007 was only performed for all 00-UTC radiosonde acscents since problems with the radiatively caused dry bias (see Section 2.9) were not expected here. It can be seen from Fig. 11 that COSMO-DE model forecasts are too dry in the boundary layer whereas they are too moist in the middle troposphere. The vertical structure for the COSMO-DE comparison is similar for all months whereas COSMOEU shows a dry bias during summer in the middle troposphere and a moist bias in the boundary layer (not shown). The largest discrepancies are obvious close to the surface pointing at some problems in the representation of the boundary layer. As expected, the RMSE increases with increasing forecast lead times.

A new perspective on the boundary layer development might be obtained from ceilometer data (see Section 2.4) which offer measurements of cloud base height (ceiling) with high temporal resolution $(10 \mathrm{~min})$. Figure 12 shows the diurnal bias of COSMO-DE cloud base vs. ceilometer cloud base for July 2007. Only data where a cloud was detected by the ceilometer and simulated by the model within the lowest $3 \mathrm{~km}$ were considered. A slight diurnal cycle can be found with the model producing higher cloud base heights compared to the ceilometer observations during the morning (roughly between 6 and 10 UTC). The model runs started at different times of the day do not differ in terms of their mean cloud base height as strongly as they do in terms of their integrated water vapour content. But some tendency similar to the one seen in the IWV appears also in the simulated cloud base height: The model runs started between 12 and 21 UTC simulate higher cloud base heights than the model runs started between 00 and 09 UTC. This might be caused by the lower water vapour content in the model runs started between 12 and 21 UTC (compare Fig. 10.) which requires a higher ascent of air par- 
cel in order to achieve condensation. In the future we will not only look at further months in order to improve the statistics but also distinguish the different synoptic situations, for example those with weak synoptic forcing. The information whether the ceilometer detects a cloud base or not can also be used to derive cloud cover statistics which will be investigated in more detail.

As a further possibility for automatic model evaluation we present the model-to-observation approach for MSG observations. For the month of July 2007 we compared the mean of the 9 MSG pixel over the AMF site (Fig. 5) with the corresponding mean of the 9 COSMO-DE pixels for different lead times (Fig. 13). The probability distribution (PD) of the difference between observed and simulated MSG brightness temperatures above the AMF site indicate different issues: The PD for the $7.3 \mu \mathrm{m}$ and $8.7 \mu \mathrm{m}$ radiances indicate how the water vapour at different atmospheric levels has been predicted. Following the weighting functions the radiances at $7.3 \mu \mathrm{m}$ mainly come from mid level atmospheric layers (between 700 and $500 \mathrm{hPa}$ ), while the radiances at $8.7 \mu \mathrm{m}$ mainly originate from the surface, whenever cloudfree conditions are present. An underestimation of the $7.3 \mu \mathrm{m}$ and $8.7 \mu \mathrm{m}$ BT by COSMO-DE can be translated into an overestimation of the predicted humidity fields in the upper as well as in the boundary layer. The significant lower predicted BT at $9.6 \mu \mathrm{m}$ might be due to higher ozone values of COSME-DE as well as an inappropriate characterisation of the SEVIRI instrument for this channel. The PDs for the $10.8 \mu \mathrm{m}$ and $12.0 \mu \mathrm{m}$ channels are both very similar and indicate that the lower brightness temperatures as predicted by COSMO-DE might come from clouds generated in COSMO-DE which are not present or have higher cloud top pressures in reality. The $13.4 \mu \mathrm{m}$ channel is sensitive to high cirrus clouds, thus the PD for this channel indicates that high cirrus clouds might not be predicted by COSMO-DE. This will be further investigated in the future by classifying cloudy and clear sky observation as well as different regions and cloud regimes.

When looking at the dependence with forecast time one can see in the atmospheric window channels that the model cold bias slightly increases with time, e.g from $3.9 \mathrm{~K}$ for the closest model forecast to $5.0 \mathrm{~K}$ for the forecast $18 \mathrm{~h}$ later. Such a difference might be explained by the occurrence and vertical position of cirrus clouds, however, similar trends are seen at other stations. Therefore the detailed observations at supersites (compare Fig. 5) will play an important role in attributing the differences to certain processes.

\section{Conclusions and outlook}

The General Observation Period 2007 gathered a large data set of in-situ and remote sensing observations for Central Europe with a focus on water cycle parameters. A near-realtime model evaluation for the COSMO-EU and COSMO-DE has been implemented for radiosoundings, surface precipitation (by RANIE), integrated water vapour content (by GPS) and cloud base height (by the ceilometer network). The first analysis already revealed important results for individual variables of the water cycle. A significant difference in the behaviour of precipitation forecasts by the COSMO models between winter- and summertime precipitation is evident; e.g. during the winter months both COSMO models overestimate precipitation by about $20 \%$. For the integrated water vapor a significant diurnal cycle in model bias could be identified and traced back to the daytime dry bias of radiosonde humidity measurements which influence the model runs started in the late afternoon. Currently similar comparisons are underway for MSG products (cloudiness, cloud top height, and synthetic brightness temperatures). After having investigated the single variables of the water cycle separately we will aim at integrated analyses including correlated behaviour of the different variables. Significant work has been done with respect to the automatization process including automatic data transfers, quality control mechanism, matching observations, and model output as well as the visualization of the results. These efforts will enable us to continue the near real-time model evaluation of the above mentioned parameters. In addition, further observations which will become timely available will be integrated. For example, this concerns the in-situ rain gauges, and the micro rain radars. For the latter several routine operators have agreed to further transmit their data to the central processing site at the University of Hamburg.

In order to get the most complete view on the year 2007 we will work on the completion of the GOP 2007 data base. In this respect, further weather services have already agreed to make data, for example for rain gauge or GPS networks, in retrospect. This will be done in cooperation with DPHASE were similar work is carried out for synoptic data. The ultimate goal is to construct a consistent, quality-proofed and easily accessible reference data set for one year at the joint data base in Hamburg.

\section{Acknowledgments}

We thank all institutions (weather services, environmental agencies, water authorities, research organisations, universities, etc.) who provided their observations and model output to the GOP. The US ARM Program provided the unique AMF to COPS/GOP. The work was funded as part of the COPS/GOP proposal by the Deutsche Forschungsgemeinschaft under grant WU 356/4-2. Part of the model evaluation was contributed by the QUEST project under grant CR 111/5-2.

\section{References}

BAldauf, M., J. Förstner, S. Klink, T. Reinhardt, C. Schraff, A. Seifert, K. Stephan, 2006: Kurze 
Beschreibung des Lokal-Modells Kürzestfrist LMK und seiner Datenbanken auf dem Datenserver des DWD. Deutscher Wetterdienst, Offenbach, 70 pp.

Bechtold, P., J.-P. Chaboureau, A. BeljaArs, A.K. Betts, M. Kohler, M. Miller, J.-L. ReDELSPERGER, 2004: The simulation of the diurnal cycle of convective precipitation over land in a global model. Quart. J. Roy. Meteor. Soc. 130, 3119-3137.

Bender, M., G. Dick, J. Wickert, T. Schmidt, S. Song, G. Gendt, M. GE, M. Rothach, 2008: Validation of GPS slant delays using water vapor radiometers and weather models. - Meteorol. Z. 17, xxx-Xxx.

BetZ, H.-D., K. SCHMidT, W.P. OETTINGER, M. WirZ, 2004: Lightning detection with 3D-discrimination of intracloud and cloud-to-ground discharges. - Geophys. Res. Lett. 31, L11108, DOI:10.1029/2004GL019821.

Bumke, K., M. Clemens, H. Grassl, S. Pang, G. PeTERS, J.E.E. SELTMANN, T. SIEBENBORN, A. WAGNER, 2005: APOLAS More accurate areal precipitation over land and sea. - Abschlussbericht, DEKLIM Forschungsprojekt des BMBF 01LD 0029, 60 pp.

DEUTSCHER WETTERDIENST (DWD), 2008: Radarverbund, Geschäftsfeld Hydrometeorolgie. Deutscher Wetterdienst, available at www.deutscherwetterdienst.de/lexikon/download.php?file= Radarverbund.pdf

Dick, G., G. Gendt, C. Reigber, 2001: First experience with near real-time water vapor estimation in a German GPS network. - J. Atmos. Solar-Terres. Phys. 63, 12951304.

Doms, G., U. SCHÄtTlER, 2002: A Description of the Nonhydrostatic Regional Model LM. Part I: Dynamics and Numerics. Deutscher Wetterdienst, available at www.cosmomodel.org/content/model/documentation/core/default.htm.

Doms, G., J. Förstner, E. Heise, H.-J. HerzoG, M. RASCHENDORFER, R. SCHRODIN, T. REINHARDT, G. Vogel, 2005: A Description of the Nonhydrostatic Regional Model LM. Part II: Physical Parameterization. - Deutscher Wetterdienst, available at www.cosmomodel.org/content/model/documentation/core/default.htm

EBERT, E.E., U. DAMrath, W. Wergen, M.E. BALDWIN, 2003: The WGNE assessment of short-term Quantitative Precipitation Forecast. - Bull. Amer. Meteor. Soc. 84, 481-492.

FABRY, F., G. L. Austin, D. TeEs, 1992: The accuracy of rainfall estimates by radar as a function of range. -Quart. J. Roy. Meteor. Soc. 118, 435-453.

FINKE, U., T. HAUF, O. KREYER, accepted: A SAFIR lightning location network in Northern Germany. - Meteorol. Appl.

Gendt, G., G. Dick, C. Reigber, M. Tomassini, Y. LIU, AND M. RAMATSCHI, 2004: Near Real Time GPS Water Vapor Monitoring for Numerical Weather Prediction in Germany, - J. Meteor. Soc. Jpn 82, 361-370.

Guerova, G., E. BrockmanN, J. Quiby, F. Schubiger, CH. MÄTZLER, 2003: Validation of NWP mesoscale models with Swiss GPS Network AGNES. - J. Appl. Meteor. 42, 141-150.

Guichard, F., D. B. Parsons, J. Dudhia, J. Bresch, 2003: Evaluating mesoscale model predictions of clouds and radiation with SGP ARM data over a seasonal timescale. - Mon. Wea. Rev. 131, 926-944.

Guichard, F., J. C. PETCH, J.-L. Redelsperger, P. Bechtold, J.-P. Chaboureau, S. Cheinet, W.
Grabowski, H. Grenier, C. G. Jones, M. KÖHLER, J.-M. Piriou, R. TAilleuX, M. TOMASini, 2004: Modelling the diurnal cycle of deep precipitating convection over land with cloud-resolving models and single-column models. - Quart. J. Roy. Meteor. Soc. 130, 3139-3172.

HAASE, G., S. CREwell, 2000: Simulation of radar reflectivities using a mesoscale forecast model. - Water Resour. Res. 36, 2221-2230.

Helmert, K., T. Hengstebeck, J. Seltmann, 2008: DWD $s$ operational tool to enhance radar data quality. - Proceedings of the Fifth European Conference on Radar in Meteorology and Hydrology, Helsinki, Finland 30 June-4 July 2008, extended abstract available at http://erad2008.fmi.fi/proceedings/

Hense, A., G. Adrian, Ch. Kottmeier, C. Simmer, V. WulfMEYER, 2006: The German Priority Program SPP1167 PQP Quantitative Precipitation Forecasting: an overview. $-2^{\text {nd }}$ International Symposium on Quantitative Precipitation Forecasting (QPF) and Hydrology, Boulder, CO, USA, June 4-8, 2006.

Illingworth, A., R. J. Hogan, E. J. O'CONnOR, D. Bouniol, M. E. Brooks, J. Delanoe, D. P. DonoVAN, J. D. EASTMEnT, N. GAussiat, J. W. F. GodDARD, M. Haeffelin, H. Klein Baltink, O. A. Krasnov, J. Pelon, J.-M. Piriou, A. Protat, H. W. J. Russchenberg, A. SEIfERT, A. M. TOMPKins, G.J. VAN ZADELHOFF, F. Vinit, U. WiLlen, D. R. WILSON, C. L. WRENCH, 2007: CLOUDNET: Continuous evaluation of cloud profiles in seven operational models using ground-based observations. - Bull. Amer. Meteor. Soc. 88, 883-898.

JoRDAn, P., A. SEED, G. Austin, 2000: Sampling errors in radar estimates of rainfall. - J. Geophys. Res. 105, 22472257.

KeIl, C., A. TAFFerner, T. Reinhardt, 2006: Synthetic satellite imagery in the Lokal-Modell. - Atmos. Res. 82, 19-25.

LÖhNERT, U., S. CREWEll, O. Krasnov, E. O'CONNOR, H. RUSSCHENBERG, in press: Advances in continuously profiling the thermodynamic state of the boundary layer: Integration of measurements and methods. - J . Atmos. Oceanic Technol.

Majewsie, D., D. Liermann, P. Prohl, B. Ritter, M. BuchHold, T. Hanisch, G. PAul, W. WerGEN, J. BAUMGARDNER, 2002: The operational global icosahedral-hexagonal gridpoint model GME: description and high-resolution tests. - Mon. Weather Rev. 130, 319338.

MAJEWski. D., H. Frank, D. Liermann, B. Ritter, 2004: Kurze Beschreibung des Global-Modells GME (40 $\mathrm{km} / \mathrm{L} 40$ ) und seiner Datenbanken auf dem Datenserver (DAS3/4) des DWD. - Deutscher Wetterdienst.

Mathes, A., P. Friederichs, A. Hense, 2008: Towards a quality control of precipitation data, - Meteorol. Z. 17, 733-749.

Matthias V., J. Bösenberg, V. Freudenthaler, A. Amodeo, D. Balis, A. Chaikovsky, G. ChourDAKis, A. Comeron, A. Delaval, F. DE TOMAsi, R. EIXMAnN, A. HÅg̊̊R, L. Komguem, S. KReipl, R. Matthey, I. Mattis, V. Rizi, J.A. Rodriguez, V. SIMEONOV, X. WANG, 2004: Aerosol lidar intercomparison in the framework of the EARLINET project. 1. Instruments. - Appl. Opt. 43, 961-976.

Mech, M., S. Crewell, I. Meirold-Mautner, C. PriGENT, J.-P. CHABOUREAU, 2007: Information content of 
millimeter observations for hydrometeor properties in midlatitudes. - IEEE T. Geosci. Remote Sens. 45, 2287-22998.

Miller, M.A., T. Slingo, 2007: The Arm Mobile Facilty and its first international deployment: measuring radiative flux divergence in West Africa. - Bull. Amer. Meteor. Soc. 88, 1229-1244.

Paulat, M., C. Frei, M. Hagen, H. Wernli, 2008: A gridded dataset of hourly precipitation in Germany: its construction, climatology and application. - Meteorol. Z. 17, 719-732.

Peters, G., B. Fischer, H. Münster, M. Clemens, A. WAGNER, 2005: Profiles of rain drop Size Distributions as retrieved by Micro Rain Radars. - J. Appl. Meteor. 44, 1930-1949.

Pfeifer, M., W. Yen, M. Hagen, G. Craig, Th. ReinHARdT, M. Mech, S. CREWEll, A. HÜNERbEIN, M. SChröder, J. Fischer, M. BALdAuf, A. SEIFERT, submitted: Validating precipitation forecasts using sensor synergy: The case study approach. - Meteorol. Z.

Rosenfeld, D., D.B. WolfF, D. Atlas, 1993: General probability-matched relations between radar reflectivity and rainfall rate. - J. Appl. Meteor. 32, 50-72

SCHRAFF, C., R. Hess, 2003: A description of the nonhydrostatic regional model LM. Part III: Data Assimilation. - Deutscher Wetterdienst, available at www.cosmomodel.org/content/model/documentation/core/default.htm

SchrafF, C., K. Stephan, S. Klink, 2006: Revised Latent Heat Nudging to cope with Prognostic Precipitation. COSMO-Newsletter 6, 31-37.

SCHRÖDER, M., N.P.M. VAN LIPZIG, F. AMENT, J.P. Chaboureau, S. Crewell, J. Fischer, V. Matthias, E. VAn MeijgaArd., A. Walther, U. WILLÉN, 2006: Model predicted low-level cloud parameters: Part II: Comparison with satellite remote sensing observations during the BALTEX Bridge Campaigns. - Atmos. Res. 82, 83-101.

SCHULZ, J.-P., U. SCHÄTTLER, 2005: Kurze Beschreibung des Lokal-Modells LME und seiner Datenbanken auf dem Datenserver des DWD. - Deutscher Wetterdienst, Offenbach, $65 \mathrm{pp}$.

SOKOL, Z., 2003: Utilization of regression models for rainfall estimates using radar-derived rainfall data and rain gauge data. - J. Hydrometeor. 278, 144-152.

Stephan, K., S. Klink, C. SchrafF. 2008: Assimilation of radar-derived rain rates into the convective-scale model COSMO-DE at DWD. - Quart. J. Roy. Meteor. Soc. 134, 1315-1326.

StePPElER, J., G. DOMS, U. SCHÄtTlER, H.W. Bitzer, A. Gassmann, U. Damrath, G. Gregoric, 2003: Meso-gamma forecasts using the nonhydrostatic model LM. - Meteor. Atmos. Phys. 82, 75-96.
Stoelinga, M. T., P. V. Hobbs, C. F. Mass, J. D. LoCAtelli, B. A. Collie, R. A. Houze, A. L. Rangno, N. A. Bond, B. F. Smull, R. M. Rasmussen, G. Thompson, B. R. COLMAN, 2003: Improvement of microphysical parameterization through observational verification experiment. - Bull. Amer. Meteor. Soc. 84, 18071826.

TIEDKE, M., 1989: A comprehensive mass flux scheme for cumulus parameterization in large-scale models. - Mon. Wea. Rev. 117, 1779-1800.

Turner, D.D., B.M. Lesht, S.A. Clough, J.C. LiljeGREN, H.E. REVERCOMB, D.C. TOBIN, 2003: Dry bias and variability in Vaisala radiosondes: The ARM experience. - J. Atmos. Oceanic Technol. 20, 117-132.

VAn Baelen, J., J.-P. AubAGnaC, Alain DABAs, 2005: Comparison of near real-time estimates of integrated water vapor derived with GPS, radiosondes, and microwave radiometer. - J. Atmos. Oceanic Technol. 22, 201-210.

VAn MeijgaARD, E., S. CREwell, 2005: Comparison of model predicted liquid water path with ground-based measurements during CLIWA-NET. - Atmos. Res. 75, 201226, DOI:10.1016/j.atmosres.2004.12.006.

VÖMEL, H., H. SELKIRK, L. MilOSHEVICH, J. VAlvarde-CANossa, J. VAldes, E. KYRÖ, W. Stolz, G. Peng, J. A. Diaz, 2007: Radiation dry bias of the Vaisala RS92 humidity sensor. - J. Atmos. Oceanic Technol. 24, 953-963.

Willen, U., S. CRewell, H.K. Baltink, O. SievERS, 2005: Assessing model predicted vertical cloud structure and cloud overlap with radar and lidar ceilometer observations for the Baltex Bridge Campaign of CLIWA-NET. - Atmos. Res. 75, 227-255, DOI:10.1016/j.atmosres.2004.12.008.

Wulfmeyer, V., A. Behrendt, H.-S. BAuer, C. Kottmeier, U. Corsmeier, A. Blyth, G. Craig, U. Schumann, M. Hagen, S. Crewell, P. Di Girolamo, C. Flamant, M. Miller, A. Montani, S. Mobbs, E. Richard, M.W. Rotach, M. Arpagaus, H. Russchenberg, P. SChlüssel, M. KÖNiG,, V. GÄrtner, R. STEINACKER, M. DORNINGER, D.D. Turner, T. Weckwerth, A. Hense, C. Simmer, 2008: The Convective and Orographically-induced Precipitation Study: A research and development project of the world weather research program for improving quantitative precipitation forecasting in low-mountain regions. - Bull. Amer. Meteor. Soc. 89, 1477-1486 DOI 10.1175/2008BAMS2367.1.

Zhang, J., U. Lohmann, P. Stier, 2005: A microphysical parameterization for convective clouds in the ECHAM5 climate model: Single-column model results evaluated at the Oklahoma Atmospheric Radiation Measurement Program site. - J. Geophys. Res. 110, D15S07, DOI:10.1029/2004JD005128, 2005 